\title{
Theorizing Financial Crimes as Moral Actions
}

Mark Lokanan

Royal Roads University, School of Business

\begin{abstract}
The paper maintains that all acts of financial crimes can be explained within a general theory of moral action and analyzed as such. In this regard, the paper presents such a theory Situational Action Theory (SAT) - and argues that acts of financial crimes result from a perception-choice process involving rational deliberation and experimental habituation, themselves the outcomes of interactions between individuals and their environments. To examine this argument, the paper draws on two recent high profile fraud cases to critically discuss the extent to which these crimes should be meaningfully and innovatively analysed as moral actions and the moral context in which they occur. The findings indicate that the feature most relevant to a criminogenic is its moral context in relation to the opportunities and frictions that it generates. As such, environmental factors along with psychosocial processes of moral education become particularly important in the explanation of why certain moral contexts emerge in particular kinds of settings at a particular point in time. In this regard, SAT can be used as a powerful overarching framework to gain a more comprehensive understanding of peoples' choice processes to breach moral rules and devise effective crime prevention strategies to combat fraud.
\end{abstract}

This paper was accepted for publication in European Accounting Review. 


\section{Introduction}

Over the last decade, the United Kingdom (U.K.) has been hit with a litany of financial scandals that sent shockwaves throughout the economy. As early as 2008, it was reported that some of the largest U.K. banks, particularly Barclays, Union Bank of Switzerland (UBS), Rabobank and the Royal Bank of Scotland (RBS), along with other international banks, were rigging the London Interbank Offered Rate (LIBOR) to increase their profit (Colombo, 2014; O'Toole, 2012). A few years after the LIBOR scandal came to light, in 2012, the New York Department of Financial Services (DFS) accused the U.K.’s fifth largest bank, Standard Chartered Bank (SCB), of hiding \$250 billion worth of transactions from Iran, Sudan, Libya and Burma through its United States (U.S.) operations (Rappaport, 2012). The U.K.'s Financial Services Authority (FSA) and the DFS accused the SCB of operating as a "rogue institution" without any regard for "national security" (Platt \& Lopez, 2012, para. 2 \& 7). In 2012, the UBS lost \$2.3 billion when trader Kweku Adoboli went rogue, trading by casting risky trades on unsuitable financial products (Russell, 2012). In 2014, the U.S and U.K. regulators fined RBS, HSBC, JPMorgan Chase, Citibank and UBS \$3.4 billion for manipulating the foreign exchange rate (Ridley, Franklin, \&

Viswanatha, 2014). In 2014, British multinational grocery and general merchandise retailer Tesco Plc ("Tesco") admitted that it had overstated its half-year profit forecast by £250m (Felsted \& Oakley, 2014). Dave Lewis, who took over Tesco as the chief executive in 2014, said he "discovered that profits for the six months to the end of August [2014] were overstated by $£ 250 \mathrm{~m}$ due to the 'accelerated recognition of commercial income and delayed accrual of costs' " (Ruddick, 2014, para. 1).

As evident from the examples noted above, financial fraud is a growing industry (ACCA, 2016). Indeed, these recent high profile cases continue to give life to the ACCA's (2016) claims 
and come with their own reflections that increase the battle cry for reforms (Power, 2013; Lokanan, 2015a). Such reforms invariably focus on surveillance mechanisms (Anand, Dacin, \& Murphy, 2014; Donegan \& Ganon, 2008; Murphy, \& Dacin, 2011; Williams, 2013) that place emphasis on understanding the personality traits of individuals who are at high risk of offending (Price \& Norris, 2009, p. 538). It is this characterisation of detecting and preventing fraud risks that inspires and motivates the present analysis. Resisting the tendency to focus on the “individualisation" and "responsibilisation” of corporate offending (Power, 2013, p. 526) that frame "fraud risks" around vectors of the individual morality of the offender, the present paper casts the analysis more broadly to examine the situational mechanisms that link the individual's action to his or her environment (e.g. see also Beneish \& Vargus, 2002; Choo \& Tan, 2007; Cooper, Dacin, \& Palmer, 2013; Donegan \& Gagon, 2008; Free \& Murphy, 2013).

One often remarked upon aspect of financial crimes is the absence of criminal prosecution for the accountants, auditors, bankers, information technology (IT) and legal experts who were all complicit in the crimes. It is alleged that the outcome of these crimes illustrates an increased focus on regulatory fines at the expense of criminal prosecution. Penalty impositions which are concentrated on regulatory fines raise concerns about whether the justice system is holding these offenders accountable to law and ethical standards (Fisher et al., 2013). In seeking answers to the constellation of rules and logics that constitutes this outcome, Mr. Andrew Tyrie (Tyrie) MP, Chairman of the Parliamentary Commission on Banking Standards (PCBS), posed a straightforward, but rather difficult, question to the three expert witnesses (Professor Julia Black, Professor David Kershaw, and Gregory Mitchell QC) on the panel for financial market regulation in the U.K:

"Despite the financial crisis and the spate of mis-selling scandals, we still have not seen anybody sent to jail. Is that because nobody ought to go to jail, or 
because there is a fundamental failure in the sanctions regime or the legal system in the UK?” (PCBS, 2013d, p. Ev 424).

In response, the expert witnesses pointed to the difficulties faced by the justice system to successfully litigate and persecute financial crimes $^{1}$ (PCBS, 2013d, pp. Ev 425-Ev 427). It is suggested that these cases illustrate an increased emphasis on regulatory fines as opposed to criminal prosecution, an approach that raises concerns with regards to deterrence (Fisher et al., 2013, p. 159).

The present paper addresses some of the concerns raised by Mr. Tyrie by conceptualising financial crime as a moral issue. This conceptualisation facilitates a theory-driven approach guided by Situational Action Theory (SAT) of crime causation and employs two criminal cases to highlight the usefulness of SAT to explain criminality: Cattles Limited (Cattles) accounting fraud and the LIBOR rate-fixing scandal. Both of these cases involved issues of morality and a particular moral context in which issues of enforcement could be analysed. Formidable as it may be, it is not my intention to outline a theoretical model of financial fraud at this time. More modestly, the purpose of this paper is to argue that acts of financial fraud result from a perception-choice process (rational deliberation and experimental habitual) and are themselves the interaction between an individual and his/her environments - specifically, the interaction between the individual's morality and the moral context in which he/she operates.

By analysing financial crimes as moral action, and the rendering of such acts as action alternatives that people choose, the analysis presented here shifts the grounds of discussion from previous research to the broader conditions of the contexts in which these crimes occurs. It is

\footnotetext{
${ }^{1}$ The terms "financial crime", "financial fraud", "fraud” “corporate crime” and white-collar crime will be used interchangeably throughout the paper. Given the nature of the paper, it was not necessary to disentangle the terms since all of them were central components of the research methodology undertaken (also see Lokanan, 2015a, p. 1; Lynch, McGurrin, \& Fenwick. 2004, p.397).
} 
hoped that, by charting this course, the paper not only provides a more nuanced understanding of financial crimes, but answers previous calls for more research in this direction (Braithwaite, 2013; Donegon \& Gagon, 2008; Lokanan, 2015b; Morales, Gendron, \& Guénin-Paracini, 2014). In line with this position, the paper makes two contribution to the accounting literature on financial crimes.

First, the literature on financial crime has largely focused on the criminogenic behaviour of the lone wolf offender as opposed to collusive behaviours that characterise much of financial criminality (Albrecht et al., 2014; Lokanan, 2015a; Murphy \& Dacin, 2011). One strong argument for SAT is that it draws on a more collective definition of morality and crime (Bouhana \& Wikström, 2008; Wikström, 2011; Wikström \& Treiber, 2009). As with groupthink and crowd behaviour, there is something inherently collective in some financial frauds and the search for distant, responsible authorities might be (sometimes) misleading. There are individual responsibilities, but the difficulty would be to prosecute groups for their collective responsibilities. This is the kind of issue being tackled by SAT and the narrowing down of fraud to individual choices of decision-making reduces the explanatory powers of conventional theories of white-collar crime causation.

Second, the paper extends the theoretical depth and range of scholarship on theories of criminal motivation by proposing a theory of action through which micro and macro level variables can be organised to identify symptoms, address causal factors, and generate new ideas to provide a robust explanation of financial fraud. While the fundamental principles of SAT are intuitive, it is by no means presented as the holy grail of fraud theories. Rather, SAT is part of the ongoing scholarship to encourage debate as we work together to tweak existing theories (Anand et al., 2014) or create new theories that capture the vast array of how fraud is perpetrated 
(Braithwaite, 2013; Donegan \& Ganon, 2008). In this regard, the postulates of SAT are seen as gateways for a more collective perspective to the study of financial fraud and answer calls for research on the macro-sociological explanation of financial crimes (Cooper et al., 2013; Davis \& Pesch, 2013; Donegan \& Ganon, 2008; Dorminey, Fleming, Kranacher, \& Riley, 2010;

Lokanan, 2015a; Morales et al., 2014).

\subsection{Explaining Crime as Moral Action}

The paper does not try to provide a concept of morality that would not be normative. Some would argue that a concept of morality that you do not find normative is just one that fits your own normativity. Hence, the question becomes one that seeks to answer how to separate what is moral and what is immoral without becoming normative. SAT does not propose to separate what is moral and what is immoral. SAT is a theory of moral action, not a moral theory of financial crimes.

In this regard, SAT does not set out to make claims about the morality of laws or of a system of laws. Rather, SAT posits that "acts of crime are best explained as moral actions that are actions guided by moral rules” (Wikström, Oberwittler, Treiber, \& Hadie, 2012, p. 12). A moral rule is a rule of conduct that dictates the right thing to do or not do is in a particular situation (p. 12). Criminal laws are a set of moral rules of conduct (p. 12). This rendering of human beings as rule-guided actors subscribes to the view that crime in the broadest sense is defined as a breach of moral rules defined in law (Cooper et al., 2013; Murphy, 2012; Murphy \& Dacin, 2011; Schuchter \& Levi, 2015). That is what all crimes, in all places, at all times, have in common (Wikström et al., 2012, p. 12). Accordingly, “all acts of violence can be explained within the general framework of a theory of moral action” (Wikström \& Treiber, 2009, p. 76). 
Any action guided by rules regarding what constitutes right or wrong in a particular situation is considered a moral action (Cohen, Ding, Lesage, \& Stolowy, 2010; Free \& Murphy, 2013; Murphy \& Dacin, 2011; Cooper et al., 2013; Stuebs \& Wilkinson, 2010). To explain acts of crime, the starting point should be to explain why people follow or break rules of conduct as stated in law (Wikström et al., 2012, p. 12). These are the phenomena that a theory of crime causation needs to explain - the factors that motivate individuals (in their environment) to break moral rules and commit criminal acts (Cohen et al., 2010; Cooper et al., 2013; Free \& Murphy, 2013; Murphy \& Dacin, 2011; Stuebs \& Wilkinson, 2010). In this regard, SAT is interested in the causes of moral rule-breaking, not in the evaluation (rightness or wrongness) of their reasons for breaking (or refraining from breaking) the law (Bouhana \& Wikström, 2008, p. 6).

The rest of the paper is structured according to the following format. I first offer an analysis of the historicity of financial crime prosecution in the U.K. and the current problems experienced by authorities responsible for investigating and prosecuting these crimes. The next section chronicles the accounting literature on the conceptualisation of financial frauds followed by a critical reflection of SAT. Next, I discuss the research design, data sources and data collection techniques used in the paper. Using data from the cases and secondary materials, I undertake a critical analysis to make a case that acts of financial crimes are essentially moral action and therefore should be analysed as such. The study then concludes with a discussion on the implications of this analysis for the future of financial crime research and scholarship.

\section{Literature Review}

\subsection{Historical and Contemporary Perspective on Financial Crime Persecution}

Historically, judges in the U.K. were reluctant to impose criminal sanctions for financial crimes (Hollow, 2015; Wilson, 2014). In the South Bubble Sea and Railway stock 
market scandals of the early $18^{\text {th }}$ and $19^{\text {th }}$ Centuries, many of the directors fled abroad and escaped prosecution for swindling investors of their life savings (Evans, 1959; Guilcher, 2005; Morgan \& Thomas 1962). The process of a new construction of financial crime can be seen in the penalties imposed on bankers William Strahan, Sir John Paul, Robert Bates (1855) and the directors of the Royal British Bank’s case (1858), Overend Gurney Ltd (1866), and the City of Glasgow Bank (1878) (Hollow, 2015, p. 8-9). Strahan et al. were charged with embezzlement of money entrusted to them as bankers and were sentenced to 14 years penal transportation (Wilson, 2014). In many ways, the Strahan et al.'s case had been tried as a straightforward criminal proceeding, i.e., their act (embezzling funds) had reduced them to the position of "common felons" (Wilson, 2014, p. 166). Contrast this to the penalties meted out to the directors in the Royal British Bank, City of Glasgow Bank, and Overend Gurney Ltd. The directors of Royal British received sentences of between 3 and 12 months, while the directors of City of Glasgow received sentences between 12 and 18 months. For similar types of crimes in Overend Gurney, the directors were acquitted and regarded as "careless", while the collapse was seen as "unfortunate"; the criminal proceedings were declared by the judge to be "vexatious and inappropriate" (Taylor, 2007). In these three cases, the directors made inappropriate loans and covered them up by fabricating the balance sheets, yet the punishments meted out were nothing more than a slap-on-the-wrist for each perpetrator.

Hardly anything has changed since the $19^{\text {th }}$ and $20^{\text {th }}$ Centuries. The opportunity for dishonest individuals to commit financial crimes has expanded with the globalisation of finance. Similar types of financial fraud are pervasive in the capital markets (Hollow, 2015). Modern capitalism is very competitive and financial crimes have become regularised to the point where many company executives may not even interpret their actions as criminal (Galbraith, 2004; 
Murphy, 2012; Murphy \& Dacin, 2011). In order for companies to remain competitive, fraud is seen as the natural order of operations (Sikka, 2010). Company executives are often "caught out in serious offences quite often for behaviour which they did not expect to be treated as criminal, and for which it is difficult to secure a conviction" (Nelken, 1994, p. 335). The issue the defendants face here is whether the conduct is seen as socially productive and, if it is, then it should not be classified as financial fraud subject to criminal prosecution (Green, 2004, p. 502).

To clear up this ambiguity, it would be helpful to know what behaviours constitute "financial crimes" and whether competing theories offer a different way of conceptualising them. Financial crimes categorised as "fraud" have been the focus of a great deal of research in criminology and accounting (Cooper et al., 2013, p. 441; Lokanan, 2015a; Lynch, McGurrin, \& Fenwick, 2004, p. 390-391; Power, 2013, p. 526). While watertight definitions of socially constructed practices are somewhat impossible, some working definitions are needed to enable dialogues, no matter how strained. The refusal to pay a fair day's wage for a fair day's work may be considered a crime by social reformers, but neoclassical economists, seeing the world through the lens of markets and commerce, would not regard this as a crime. So whose theories and conceptualisations are in ascendancy and why? Typically, accounting and audit research sum up financial crime to mean (1) acts involving the manipulation of records and accounts and (2) fraud involving theft or embezzlement for personal gains (Matthews, 2005, p. 520). This individualistic explanation is built on a construction that sees fraud as being committed by an individual with a "frail morality" whose behaviour can be address by after-the-fact intervention today’s policy obsessions (Morales et al., 2014, p.177; Power, 2013, p. 526).

There are, however, fundamental problems with this conceptualisation. First, a significant proportion of financial fraud consists of regulatory offences and can only be dealt 
with in administrative proceedings. For example, earnings management can be a signal of dishonest management or a signal leading to misleading financial performance and may have criminal elements attached to it, but at the same time, it is measured in shades of grey (Beasley, Carcello, Hermanson \& Neal, 2010; Beneish \& Vargus, 2002; Jones, 2011; Macintosh, 2009). As a matter of fact, earnings management and income smoothing are sometimes classified as prudent management and supported by regulators (Cooper et al., 2013, p. 441). Second, it is highly likely that the actus reus (guilty act) of a conduct can be proven beyond a reasonable doubt in criminal proceedings. The problem arises, however, in establishing the mens rea (guilty mind) associated with the offence. For instance, in cases involving misrepresentation of reports, the company executives are aware that it is virtually certain that the company will be affected if they get caught. They usually do not want this to happen. The company executives have direct intentions to misrepresent the reports, but indirect intentions of causing reputational risks or the collapse of the company. Consequently, criminal prosecution becomes difficult when the actus reus and mens rea are not aligned.

In sum, most of the activities described and considered as crimes are not prosecuted as such. Prosecutors are very reluctant to impose criminal sanctions and usually prefer administrative sanctions instead. The historical background discussed earlier is very interesting in this respect. The specificity of white-collar crime is that it is concerned with people powerful enough to influence legislation (Sutherland, 1937). As is clear from the historical cases, the "good family background" and "gentleman" character of the persons concerned help them avoid or soften prosecutions when they are caught. But this also explains (according to Sutherland (1937) why so many activities are not even considered as crimes by the law (although they are harmful and could fit a broader definition of crime). As Sutherland (1937) would see it, what 
helps white-collar criminals to escape the crime stigma is not only the reluctance of prosecutors, but also of legislators who adopt restrictive definitions of crime for activities usually performed by business elites. This is interesting to note because it does not seem to complicate things that much when prosecuting "street crimes". So, again, prosecution only favours the powerful (Dellaportas, 2013; Matthews, 2005; Mitchell, Sikka, \& Willmott, 1998).

\subsection{Individual Decision Making and the Choice to Offend In Accounting Research}

A growing body of research in accounting including a special issue in Accounting, Organizations and Society (2013) represents a particular analytical lens that focuses on decision making and processing strategies employed by individual offenders in their decision to offend (Braithwaite, 2013; Cooper et al., 2013; Davis \& Pesch, 2013; Gabbioneta, Greenwood, Mazzola, \& Minoja, 2013; Neu, Everett, Shiraz, Rahaman, \& Martinez, 2013b; Power, 2013; Williams, 2013). These complementary pathways are rooted in rational choice and economic agent models that lend themselves to a variety of analytical interpretations in fraud research (Hoffman \& Zimbelman, 2009; Murphy \& Dacin, 2011; Powers, 2013; Strand Norman, Rose, \& Rose, 2010). Wedded to the view that individual actors have a choice to offend or desist from offending, this strand of literature epistemically frames the individual's decision into three schematically constructed areas: the lone wolf predatory offender; the dominant decision maker; and the hybrid offender.

Accounting research on lone wolf predatory offending associate financial fraud with moral defects and isolate offenders as discrete decision-making and risk-taking actors (Dorminey, Fleming, Kranacher, \& Riley, 2012; Lokanan, 2015a; Murphy, 2012; Neu, Everett, \& Rahaman, 2013a; Ramamoorti, 2008; Wolfe \& Hermanson, 2004). These scholarly accounts are the leading sources of a diagnostic project in accounting and fraud literature that 
characterises the lone wolf offender in frames of etiological clusters: neurotic personality (Dorminey et al., 2010), an inclination to cheat (Wolfe \& Hermanson, 2004), higher Machiavellian scores (Murphy, 2012) and having psychopathic tendencies (Ramamoorti, 2008). In a manner analogous to the diagnostic project, these classifications, for the most part, coalesces around the notion that the predatory offender is “driven by need” (Donegan \& Ganon, 2008, p. 3) and by virtue of being better organised, the lone-wolf offender will seek to make a decision that maximises his or her own net utility in each situation (Albrecht \& Albrecht, 2004; Davis \& Pesch, 2013; Stalebrink \& Sacco, 2007). This attributional stance posited "that actors weigh costs and benefits of wrongdoing and embark on fraud when they conclude that the benefits outweigh the costs" (Cooper et al., 2013, p. 442).

Others look at the decision to offend through the lens of the dominant decision maker (Beasley et al., 2010; Choo \& Tan, 2007; Farber, 2005; Macintosh, 2009; Power, 2013). Cast in terms of an institutional apparatus, the most striking feature of this account is that organisational leaders engage in corporate misconduct against the organisation, its employees and stakeholders (Power, 2013, p. 539). At play in this representation is the claim that fraudulent practices "follow a path of institutionalization, which converges on senior management as the responsible agent” (Power, 2013, p. 539). Notwithstanding the organisation's promise to its stakeholders to act ethically and maximise profit, Sikka (2010) in his work on tax avoidance noted that fraudulent practices have come to represent the naturalness and normalcy of organisational life (see also Bell \& Carcello, 2000; Erickson, Hanlon, \& Maydew, 2006; O’Connell, 2004; Strand Norman et al., 2010). Rogue leaders, as they are referred to by Power (2013), use these organisations to engage in fraud against stakeholders with a mixture of false accounting and misrepresentation (Power, 2013, p. 539). The promise of ethical behaviour is decoupled from the practice of 
maximising profit through fraudulent practices (Sikka, 2010, p. 165). In either scenario, the elements that "remains misrecognized" are the possibility that deception and manipulation becomes normal features of a well-functioning organisation (Williams, 2008, p. 480).

The third variant of the decision-making process involves hybrid offenders (Power, 2013; Cooper et al., 2013). In hybrid offending, the target is the organisation itself (Clikeman, 2009; Jones, 2011; Gabbioneta et al., 2013; Matthews, 2005; Neu et al., 2013a; Rezaee, 2005). Contemporaries such as Power (2013) argued that hybrid offending involves both executives and employees and implicates the entire organisation in financial fraud (p. 539). Collusion and organisational culture are considered the key nodes of problematisation and represent a more systemic expression of institutionalised corruption and financial fraud (Ashforth \& Anand, 2003; Lehman \& Okcabol, 2005; Lokanan, 2014; Neu et al, 2013; Power, 2013) that is facilitated by an inadequate and compromised internal control system (Beneish, Billings, \& Hodder, 2008; Gabbioneta et al., 2013; Rae \& Subramaniam, 2008; Rezaee, 2005). Farber (2005) and later Donegan and Ganon (2008) further emphasised that group qualities of trust and loyalty serve as purported attributes through which opportunities for committing fraud become apparent to organisational leaders and employees. These accounts lend ontological weight to the subtext that the opportunity to commit fraud is not something that is suddenly discovered, as in a street deviant who steals the jeweller's watch while the jeweller was away from the counter; rather, as Davis and Pesch (2013) so eloquently put it, the opportunities are cleverly camouflaged in a structured system of well-organised interdependent actors.

This manifestation of fraud and fraud risks encourages auditors to look for fraud in areas where there are individual risks and shifts organisational surveillance to systems of controls (Gietzmann \& Pettinicchio, 2014; Lokanan, 2015a; Power, 2013; Williams, 2013). Indeed, this is 
reflected in the American Institute of Certified Public Accountant (AICPA) adoption of the fraud triangle (FT) as a model to detect and prevent corporate accounting fraud. This adoption was evident in the Statement on Auditing Standards (SAS) no. 99, Consideration of Fraud in a Financial Statement Audit, which is now the cornerstone of the AICPA's anti-fraud program. SAS 99 affirmatively states that the three conditions that make up the FT are generally present when fraud exists: "incentive/pressure to perpetrate fraud, an opportunity to carry out the fraud, and attitude/rationalization to justify the fraudulent action” (AICPA, 2002, para. 33 emphasis added). Yet there is no better proof of the failure of prevention, detection and enforcement policies adopted and agreed upon by standard setters than in the increased frequency of fraud and more specifically financial crimes across the globe (PwC, 2016).

The micro-epistemological framing serves to sustain a narrow conceptualisation of fraud and prevention (Stalebrink \& Sacco, 2007). Many individuals are exposed to various pressures and opportunities to commit fraud but, despite this exposure, a significant number of them choose not to engage in fraudulent behaviour (Greve, Palmer, \& Pozner, 2010; Lokanan, 2015a; Morales et al., 2014; Powers, 2013). Another way is to ask why some individuals, for example, take actions to distort financial results, while others in similar situations do not? Researchers have dedicated a great deal of effort to try and answer this question. The answer for some lies with structural theories of motivation (Albrecht et al., 2014; Coleman, 1987; Cooper et al., 2013; Davis \& Pesch, 2013; Donegan \& Gagon, 2008; Gabbioneta et al., 2013; Wikström, 2004, 2010a). These scholars give importance to the context and environmental characteristics the individual is immersed in and how the various interactions within this system influence the individual's behaviour (Coleman, 1987). 


\subsection{The Structural and Contextual Features of fraud in Accounting Research}

The existing accounting literature has been particularly remiss in its treatment of the contextual and structural features of financial fraud (e.g. see Choo \& Tan, 2007; Cooper et al. 2013; Donegan \& Gagon, 2008; Lokanan, 2015a). However, of late, a small, but emerging band of accounting scholars have started to step out of this ontological box and portray financial fraud less as the result of individual deviance and more as the outcome of societal and organisation collusion (Braithwaite, 2013; Dedoulis, 2006; Donegan \& Ganon, 2008; Free, Macintosh, \& Stein, 2007; Free \& Murphy, 2013; Gabbioneta et al., 2013; Stuebs \& Wilkinson, 2010). Consistent with a critical stream of sociology of deviance research (Coleman, 1987; Gottfredson \& Hirschi, 1990), this position embodies a reified view of the interaction between individuals, institutions and the environment as the causes of criminality (Dorminey et al., 2012; Murphy \& Dacin, 2011; Murphy \& Free, 2016).

Theories that focus on structural variables acknowledge that the environmental context in which crime takes place consists of a complex systematic process that relies on the interaction between the individual and structural factors (Donegan \& Gagon, 2008; Gabbionetta et al., 2013; Lokanan, 2015a; Morales et al., 2014; Sikka, 2008). Cooper et al. (2013) writing through this interpretive frame noted that "contextualizing frauds, suggests that accounting fraud needs to be understood in a social, legal, political and economic context, such as whether a particular society encourages (or not) risk taking, socializes losses, or encourages rule following” (p. 441). As Donegan and Gagon (2008) put it, the interrelated dynamics of institutional and structural variables all contribute to offending behaviours. Given this interconnection, structural theorists argue that crime is socially constructed and as such, the macro-level variables must be incorporated into the explanation (Dedoulis, 2006; Gabbioneta et al., 2013; Morales et al., 
2014;Stalebrink \& Sacco, 2007). Lokanan (2015a) echoes Morales et al. (2014) and Free and Murphy’s (2015) positions in arguing that a macro-level analysis of crime will allow policymakers to focus on interventions that emphasise the development of human beings from inception, as they are caught up in a web of relations that antedates any individual acts of deviance.

Given the societal conflict that these individuals are in, financial fraud will be more prevalent in occupational subcultures that nurture and rationalise such behaviours (Coleman, 1987). Each complex organisation has an "ethical tone" that either reinforces or opposes rule violations (Albrecht et al., 2014; Cohen et al., 2010; Davis \& Pesch, 2013; Gabbioneta et al., 2013). An industry subculture that fuels unethical behaviour quickly cuts into the occupational subcultures in organisations (e.g., accounting, law, or medicine) that characterise that industry and are then rationalised as the conventional way of doing things (Murphy \& Dacin, 2011). Industry subcultures that are favourable to criminogenic behaviour can be incorporated into organisational subcultures that are able to maintain certain criminal activities as acceptable or recognised behaviour (Cohen et al., 2010; Clor-Proell, Proell, \& Kaplan, 2015; Payne, 2012).

Neither individual nor structural theories of criminal motivation can explain the acts of fraudsters who plan to commit crime from the moment they are hired or became part of the organisation (Kardell, 2015). These are individuals who commit crimes because of a lack of morals and character flaws (Kardell, 2015, para. 12). A weakened moral conviction, character flaws and criminogenic environment all combine to make people susceptible to criminogenic behaviour (Kardell, 2015, para. 13). In coming up with explanations for financial fraud, it must be acknowledged that limits and boundaries to their intelligibility and knowledgeability exist because all approaches offer partial explanations. To re-evaluate and re-describe financial fraud 
requires researchers to transcend the complicity between criminology and accounting scholars both of whom remain wedded to a reified view of fraud and fraud risk - and focus instead on a plurality of approaches; SAT is one of them. ${ }^{2}$

\subsection{Situational action theory of crime causation: A Brief Overview}

Based on the discussion so far, two central features in explaining criminality emerge; these are the individual propensity to commit crime and the environment and structural conditions to which the individual is exposed to. These two views are rarely ever combined, although there is no shortage of scholarship in both social science and accounting literature that argues for the integration of these two approaches to advance understanding on the aetiology of crime (Barak, 1998; Cooper et al., 2013; Donegan \& Gagon, 2008; Jeffrey, 1990; Morales et al., 2014). SAT is a newly developed theory that aims to unify individual and structural explanatory perspectives from criminology and social and behavioural sciences more generally to explain crime as moral action (Bouhana \& Wikström, 2008, 2011; Wikström \& Treiber, 2009;

Wikström, 2010a, 2010b, 2010c; Wikström et al., 2012).

The basic SAT model proposes that criminal actions (C) are the outcome of a perceptionchoice process as a situational mechanism that is initiated and guided by the interaction of an individual's propensity (P) and exposure to criminogenic environments (E) (Wikström, 2010b).

The assumption that SAT makes is:

\section{Propensity x Exposure $=$ Crime}

At the heart of this equation is the notion that "people's actions are an outcome of a perceptionchoice process initiated and guided by the person-environment interaction” (Wikström et al., 2012, p. 10). The individual's propensity to see crime as a general action alternative is

\footnotetext{
${ }^{2}$ I would like to acknowledge one of the anonymous reviewers for suggesting this point.
} 
determined by his or her morality and ability to exercise self-control (Hirtenlehner, Pauwels, \& Mesko, 2014, p. 133). In this regard, SAT views acts of crime as moral action i.e. the right or wrong thing to do or not do in particular circumstances and should be analysed and explained as such (Wikström \& Treiber, 2009, p. 76). The choice-making process can be "more or less habitual or deliberate depending on the subject's degree of familiarity with the setting he or she takes part in and its circumstances” (Wikström, 2015, p. 254). Familiarity "with the setting and circumstances promotes habitual (automated) processes of action, while unfamiliarity with a setting and circumstances promotes deliberate (rational and reflective) processes of action” (p. 254). SAT combines this dual choice process (habit and deliberation) and puts forward an argument that attempts to make sense of crime causation and to reconcile the apparent contradictions between individual and structural explanations of crime.

While the literature provides empirical support for the core assumptions of SAT (Hirtenlehner et al., 2014; Hirtenlehner \& Hardie, 2016; Pauwels \& Svensson, 2010), one of the fundamental problems associated with its application is that the analysis of interactive relationships is often characterised as problematic (Hirtenlehner \& Hardie, 2016). The argument here is that, under some conditions, there is not much support for the proposition that individuals with low morality and low self-control are more susceptible to peer influence (Bruinsma, Pauwels, Weerman, \& Bernasco (2015). A more synonymous limitation of SAT is that measures of association with peers who have criminogenic tendencies or who have crime-conducive moral rules represent a narrow definition of exposure to criminogenic settings. Such characterisation and classification does not capture other important aspects of moral context, such as the presence of individuals with poor collective efficacy (Hirtenlehner \& Hardie, 2016, p. 327). Another limitation with SAT is that many individuals may experience criminogenic settings, but will not 
break moral rules to overcome the conditions in those settings. Consequently, an argument can be made that SAT has limited explanatory power (Pauwels \& Svensson, 2010). However, this is a problem with all theories of crime causation (Choo \& Tan, 2007; Cooper et al., 2013; Donegan \& Gagon, 2008; Dorminey et al., 2010). The explanation remains in the choices of the individual.

One can understand this as similar to Sartre's (1943) argument: free choice is what makes people responsible and accountable for their actions. But this does not fit so well with the claim that structure and context influence human actions (i.e., choices available to individuals due to their desires). Human actions (including acts of collusion to perpetrate fraud) must, therefore, be explained as rule-guided action (Bouhana \& Wikström, 2008, p. 39). SAT combines this choice process (habit and deliberation) and puts forward the argument that this dual process provides a powerful theoretical framework to understand the interrelated, underlying causal factors by linking causes to outcome as is required of a theoretical model of financial fraud.

\section{Methodology}

\subsection{Research Design}

The present paper employed a multi-method case methodology to explore the application of SAT to financial fraud. Two high profile cases, which involved breaches of the FSA's Principle of Business, were used in the paper. To give perspective, I use SAT to guide the case selection process. SAT is a powerful framework for organising and analysing the known facts of these cases by identifying the symptoms that led to the perception-choice process and action alternatives they chose and carried out (Bouhana \& Wikström, 2008, p. iv).

Two main themes of SAT guided the case selection. The first of these is informed by Wikström's (2004) micro-level analysis of the individual choice process. At the micro level of 
analysis, the cases selected reflect how different individual characteristics and moral habits affect peoples’ behaviour (Wikström, 2013). The situational factors are explored and are best analysed as the "causes" of crime (Wikström, 2010a, pp. 216-217). The second theme is the macro sociostructural level of analysis and is best seen as the "causes of causes” of crime (Wikström, 2010a, pp. 216-217). At the macro level, SAT is interested in how the characteristics of the broader environment affect the activities that takes place in the institutions (as in financial crimes) and, by extension, the wider environmental characteristics that shapes habitual actions (Wikström, 2013). The macro-level analysis takes into consideration the effects of groupthink and its influence over collective criminal behaviour. Taken together, SAT seeks to bridge the micro and the macro divide in distinguishing the "causes" from the "causes of the causes" when analysing the aetiology of crime (Barak, 1998; Choo \& Tan, 2007; Coleman, 1987; Cooper et al., 2013; Lokanan, 2015a; Sikka, 2015).

\subsubsection{Case Selection}

By reading various news outlets and the FCA's Notice of Hearings, I was able to collate a short list of cases on which there was sufficient information to carry out a critical analysis of the moral actions of individuals and their associations with financial crimes. The cases selected involved both individuals within the organisation and the organisations themselves. Particular emphasis was placed on the broader institutional and socio-cultural characteristics ("causes of causes") to understand the choice process ("causes”) of individuals or group of individuals colluding to commit financial fraud. The objective was to select cases that would provide the greatest possible insights and information to explain the moral actions of individuals within their situational and environmental settings. 
To provide perspective on the individuals' choice process and subsequent action alternative, I used the Cattles Limited (Cattles) accounting fraud and London Interbank Offered Rate (LIBOR) scandal as prototypical cases that have properties which are typical of cases in this genre (see Brennan \& Conroy, 2013; Flyvbjerg, 2006; Lakoff, 1987). The cases selected represent a general trend and, in the case of the LIBOR scandal, precipitated the Global Financial Crisis (GFC) that triggered a worldwide debate on fraud among banks (see Lokanan, 2015a). Taken together, these two cases provide for an analysis of why individuals vary in their propensities to commit crime and why the structural settings in which they are embedded become criminogenic (Wikström, 2011, pp. 68-69). The next section provides details on the three data sources used in the paper: Cattle Plc and LIBOR cases; written evidence and transcripts from the PCBS Hearings; and government responses to the PCBS final report.

\subsection{Data Source 1}

\subsubsection{Case 1: Cattles Plc}

Cattles was founded in 1927 and is based in the United Kingdom. Cattles was a publicly listed financial service company that had been admitted to the London Stock Exchange (LSE) since 1963. Between 2007 and 2009, Cattles, then Cattle Plc, was a subprime lender on the LSE and conducted most of its business through its subsidiary, Welcome Financial Services Limited (Welcome). The principal business of Welcome was to secure growth by providing loans to nonstandard customers; debt purchase services; and debt recovery and investigation services to banks, catalogue retailers and utility companies. At all material times, Cattles’ finance director was James Corr (Corr), while Peter Miller (Miller) was the finance director and James Blake (Blake) the managing director of Welcome. As the finance director, Corr was responsible for 
Cattles' financial statements and to ensure that all the financial information was provided to its external auditors PricewaterhouseCoopers (PwC).

At issue in this case is that Cattles published false and misleading financial information about the credit quality of Welcome in its 2007 Annual Report. More specifically, Cattles stated that, as of December 31 $1^{\text {st }}$, 2007, around $£ 2.1$ billion of its $£ 3$ billion loan book was not in arrears. Cattles advertised this position in its Rights Issue Prospectus in April 2008 and raised £200 million (Holt, 2012, para. 6). As a result of this falsification, Cattles violated International Financial Reporting Standard (IFRS) 7 and misled investors and made a pre-tax profit of $£ 165.2$ for the year ended December 31, 2007 (FSA Final Notice to Cattles, 2012b, p. 3). In handing out penalties, the FSA found that Cattles' directors misled investors by approving and signing off on audited financial statements as to the veracity of the information provided to compile Cattles' 2007 Annual Report. In so doing, the directors overlooked their duties to the companies and shareholders by distributing false and misleading information of the company's shares. The directors were fined and banned from taking part in any business overseen by the FCA: Corr was fined $£ 400,000$, Miller $£ 200,000$ and Blake $£ 100,000$ for market abuse.

\subsubsection{Case 2 Libor}

The LIBOR is the primary benchmark for short-term interest rate at which banks theoretically lend to each other in the overnight market (Fisher et al., 2013, p.159). The LIBOR "rates are calculated by Thomson Reuters for ten currencies with 15 maturities ranging from overnight to 12 months” (Monticini \& Thornton, 2013, p. 1). To determine the LIBOR, contributing banks are asked to provide an answer to the following question: "At what rate could you borrow funds, were you to do so by asking for and then accepting inter-bank offers in a reasonable market size just prior to 11 am?” (Monticini \& Thornton, 2013, p. 1). Once the rates 
are submitted, the lowest and highest quartiles are ignored. The average rate is then calculated by the remaining submissions to arrive at the LIBOR at which banks are willing to lend. Beginning in 2007, accusations began to surface that derivatives traders in certain banks were manipulating the LIBOR in order to protect their trading positions (Fisher et al., 2013, p. 159). In 2008, an article appeared in the Wall Street Journal ("WSJ") that upheld the accusation that the LIBOR rates were different from the WSJ's calculation of the average interest rates (see Mollenkamp \& Whitehouse, 2008). The entire LIBOR scandal came to light at the height of the GFC when in 2008 a Barclays’ employee queried by a New York Federal official explained that Barclays was underreporting its rates.

To represent the entirety of the LIBOR fraud, three of the banks that were charged with fixing the rates were chosen for this study: Barclays Plc (Barclays), Union Bank of Switzerland (UBS) and Royal Bank of Scotland Plc (RBS). These banks were selected because they (1) provide the greatest insights into the moral norms and settings constitutive of the LIBOR fraud, and (2) provide valuable information that will allow for an analysis of the criminogenic elements that characterise the LIBOR fraud. The selection of the three banks is distinct from a single bank in that they allow for integrity, that is, the totality from the wider environment of the LIBOR fraud. A brief description of the types of criminogenic behaviour in which the banks were involved and the penalties imposed by regulators are outlined below.

\subsubsection{Barclays}

Between 2005 and 2008, Barclays Plc (“Barclays”) through its managers and traders located in London, New York and Tokyo repeatedly manipulated and made false and inaccurate submissions regarding the LIBOR rate. Barclays' manipulative conduct involved the United States Dollar ("U.S. Dollar"), Sterling, Euro and Yen. Barclays routinely conveyed misleading 
reports that its submitted LIBOR rates were based on the cost of borrowing unsecured funds in the interbank market. It was alleged that Barclays breached Principles 2, 3 and 5 of the FSA's Principles for Business in that it did not have any specific systems of controls relating to its LIBOR submission; Barclays failed to review its risk management and control systems; and failed to deal with the rigging internally when it was first detected in 2007 (FSA Final Notice to Barclays, 2012a, pp. 2-4). For knowingly submitted false and misleading information that negatively affected the LIBOR and brought the financial markets into disrepute, the FSA in June of 2012 imposed a financial penalty of $£ 59.5$ million on Barclays. Barclays was also fined $\$ 710$ million by the U.S. Department of Justice (DOJ); \$485 million by the New York State Department of Financial Services and \$400 million by the U.S. Commodity Futures Trading Commission (CFTC).

\subsubsection{UBS}

During 2005 to 2008, managers, agents and traders of UBS engaged in systemic misconduct that undermined the integrity of the LIBOR rates. It is alleged that UBS made false submissions to rate-fixing panels to benefit its derivative trading position. For certain currencies and benchmark interest rates, UBS derivative traders also colluded with traders at other banks to manipulate the LIBOR rates it submitted on a routine basis (FSA Final Notice to UBS 2012c, p. 11). UBS was charged with breaching Principle 3 of the FSA's Principles for Business by failing to take reasonable care and not having an adequate risk management system in relation to its LIBOR submissions process. UBS also breached Principle 5 by failing to observe proper standards of market conduct. For these violations, the FSA in December of 2012 fined UBS £160 million for manipulating the benchmark interest rate. UBS was also fined \$203 million by the DOJ in connection with LIBOR rigging. 


\subsubsection{RBS}

From 2006 to 2008, RBS was involved in manipulation of submissions to benefit its derivatives trading books. RBS managers and traders working in tandem with other panel banks made numerous attempts to manipulate the Yen and Swiss Franc LIBOR (CFTC RBS, 2013, p. 2). During this period, RBS breached Principle 5 by manipulating its submissions and Principle 3 for failing to have adequate internal controls and procedures to observe proper standards of market conduct (FSA Final Notice to RBS, 2013, pp. 2-4). The FSA imposed a financial penalty of $£ 87.5$ million on RBS for breaching Principles 5 and 3. RBS was also fined $\$ 395$ by the U.S. DOJ and $\$ 325$ by the U.S. CFTC.

\subsection{Data Collection}

\subsubsection{Cattles Plc}

Cattles’ consolidated interim financial reports (Reports) were collected between 2007 and 2009. Financial data from the Reports were collected from 2007, when the fraud first surfaced, to 2009, when the fraud was discovered and came under the jurisdiction of the FSA. The financial data were employed to evaluate Cattles’ original and reinstated loans and receivables as well as its pre-tax profit, both before and after the fraud. For the first time, in 2007, Cattles’ Annual Report was required to be prepared in accordance with IFRS 7. In this regard, the data from the Reports were used to analyse Cattles’ compliance with the action - relevant rules (i.e., IFRS 7) that were implemented to guide and regulate financial reporting (moral action).

Data on Cattles’ legal issues and enforcement came from FSA Final Notices (Notices). The Notices consist of detailed material facts of the cases for Cattles and the individual directors, respectively. The information from the Notices helped to understand the breaches of the FSA's Principles of Business (moral rules) and the situational factors and the procedures that Cattles' 
directors employed to circumvent IFRS 7. More importantly, the Notices provided valuable information on how Cattles' directors conceptualised the fraud and helped to reconstruct the conception, evolution, concealment and ultimate detection of the fraud. Together the data from the Reports and the Notices allowed for a more nuanced understanding of the evidence emerging from an analysis of the moral context in the Cattles case. Table 1 provides excerpts of the texts that were analysed from the Cattles case.

Table 1: Cattles' Case Facts

\begin{tabular}{|c|c|c|}
\hline $\begin{array}{l}\text { SAT's } \\
\text { Aggregate } \\
\text { Themes }\end{array}$ & $\begin{array}{l}\text { Major } \\
\text { Assumptions } \\
\text { of SAT }\end{array}$ & Cattles \\
\hline & $\begin{array}{l}\text { The moral } \\
\text { rule violation }\end{array}$ & $\begin{array}{l}\text { IFRS } 7 \text { paragraph } 31 \text { establishes a key principle, namely that companies should } \\
\text { "disclose information that enables users to evaluate the nature and extent of } \\
\text { risks arising from financial instruments to which the entity is exposed" (IFRS } \\
7.31 \text { ). }\end{array}$ \\
\hline $\begin{array}{l}\text { Crime as } \\
\text { moral } \\
\text { action }\end{array}$ & $\begin{array}{l}\text { Why break } \\
\text { moral a rule? }\end{array}$ & $\begin{array}{l}\text { Cattles' IFRS } 7 \text { project team informed the director "that it 'would appear a } \\
\text { challenge to argue that debt having deferments is neither renegotiated nor in } \\
\text { arrears' and took the correct view that deferments fell to be disclosed as either } \\
\text { past due or renegotiated loans but [the director], aware that this would have } \\
\text { involved disclosing a significant proportion of the loan book as renegotiated, } \\
\text { told the project team that he were reluctant to accept this view...because it } \\
\text { would mean disclosing 34\% of the loan book as either renegotiated or as past } \\
\text { due (FSA, 2012e, p. 11-12). "The clear inference is that such a disclosure was } \\
\text { deemed "unacceptable" to the business because it would reveal significant } \\
\text { negative information about the credit quality of the loan book" (FSA, 2012e, p. } \\
\text { 12). }\end{array}$ \\
\hline & $\begin{array}{l}\text { Opportunities } \\
\text { and } \\
\text { Temptations }\end{array}$ & $\begin{array}{l}\text { Cattles "made extensive use of 'deferments' whereby missed contractually due } \\
\text { payments could be deferred to the end of the loan period, usually without } \\
\text { contacting the relevant customer, and a deferment was deemed to either restart } \\
\text { or pause the arrears clock, depending on the circumstances" (FSA, 2012b, p. 4). }\end{array}$ \\
\hline $\begin{array}{l}\text { Situational } \\
\text { mechanisms }\end{array}$ & $\begin{array}{l}\text { Frictions and } \\
\text { Provocations }\end{array}$ & $\begin{array}{l}\text { "Neither PwC nor its Audit Committee were aware of the significance of the use } \\
\text { of deferments within the business and, despite this being obviously relevant } \\
\text { information to an assessment of the credit quality of the loan book, [Cattles] } \\
\text { took insufficient steps to ensure that PwC and its Audit Committee understood } \\
\text { the significance of deferments" (FSA, 2012b, p. 4). } \\
\text { Cattles directors "“signed the representation letter to Cattles' auditor } \\
\text { PricewaterhouseCoopers ("PwC") as to the veracity of the information provided } \\
\text { to compile the Cattles } 2007 \text { Annual Report" (FSA, 2012d, p. 4). }\end{array}$ \\
\hline
\end{tabular}




\section{Context}

Context of development

Context of
At a Cattles’ Audit Committee meeting with its IFRS project team "PwC outlined the IFRS 7 requirements as understood by them, without referring to the question whether deferments should be disclosed as renegotiated loans (or indeed as past due loans)" and Cattles directors did not "highlighted that fundamental issue” (FSA, 2012d, p. 11).

PwC explained that “... this might produce some strange looking numbers because the standard related to the debt which was not repaid in accordance with its contractual terms and this was in the ordinary course of business for [Welcome]" (FSA, 2012b, p. 12).

In subsequent meetings the project team reported that "IFRS 7 meeting with PWC also went very well ... there was absolutely no mention of deferments ... as they did not raise any challenge re deferments, we did not raise it either. I feel that deferments are not particularly on their radar screen either re IFRS 7 or generally and I suggest we keep it that way” (FSA, 2012e, p. 13).

Cattles' directors “were aware in the months leading up to signing Welcome's 2007 Annual Report that deferments were not on PwC's "radar screen” but did not ensure that they were properly informed” (FSA, 2012e, p. 13).

Cattles directors signed a representation letter to $\mathrm{PwC}$ in connection with its audit of the financial statements of Cattles for the year ended 31 December 2007 and made the following representations: "Each director has taken all the steps that he or she ought to have taken as a director in order to make himself or herself aware of any relevant audit information and to establish that [PwC] are aware of that information, including that ... All other records and related information which might affect the truth and fairness of, or necessary disclosure in, the financial statements ... and no such information has been withheld" (FSA, 2012e, p. 17).

"So far as each director is aware, there is no relevant audit information of which [PwC is] unaware.”; and that “... the financial statements are free from material misstatement, including omissions” (FSA, 2012e, p. 17).

Without having made adequate enquiries to satisfy themselves that these statements were free from material misstatement, Cattles' directors "approved the Cattles’ 2007 Annual Report... on 28 February 2008” (FSA, 2012b, p. 17).

\subsubsection{LIBOR}

Data for the banks were collated from the transcripts of the regulatory investigations into

the LIBOR rate-setting process. These include civil cases of the banks that were heard by the

CFTC and the Financial Service Authority’s (FSA) Notices. CFTC's decisions are published as

"Orders" and provide detailed accounts of the managers and traders' actions in the scandal. The

Orders used in this paper were limited to Barclays, RBS and UBS because they provide the

greatest amount of material information on the LIBOR fraud. The FSA's Final Notices were

used to provide a regulatory perspective on the actions of the banks involved in the LIBOR 
scandal. Together, the CFTC's Orders and the FSA's Notices helped guide the inquiry and

provided greater insights into the actions of the actors involved in constructing the scandal. Table

2 displays excerpts from the cases that were used to apply SAT to the LIBOR fraud.

Table 2: LIBOR Case Facts

\begin{tabular}{lll}
\hline SAT's & Major & \\
Aggregate & Themes & LIBOR - Barclays, UBS and UBS \\
Assumptions & &
\end{tabular}

“Over a period of several years, commencing in at least 2005 ...Barclays through the acts of its swaps traders and submitters made false LIBOR reports and attempted to manipulate LIBOR” (CFTC, 2012, p. 5). "From at least January 2005 through at least June 2010 UBS, through the acts of its derivatives traders, benchmark interest rate submitters and managers, made false benchmark interest rate submissions in an effort to The moral manipulate the official fixings of Yen, Swiss Franc, Sterling and Euro rule violation LIBOR, Euribor and Euroyen TIBOR” (CFTC UBS, 2012, p. 5). "Commencing in at least mid-2006, RBS, through the acts of its derivatives and money market traders ... attempted to manipulate the fixings of Yen

\section{Crime as} Moral Action

Situational mechanisms
Frictions and Provocations and Swiss Franc LIBOR. On a number of those occasions, RBS made false LIBOR submissions in furtherance of its manipulative attempts, which at times were successful (CFTC RBS, 2013, pp. 3-4).

Barclays' traders engage in "manipulation of submission to benefit its derivatives trading books" (FSA, 2013, p.2).

UBS traders engage in "manipulation of submission to benefit its trading Why break position” (FSA, 2012c, p. 2).

moral rules? RBS traders engaged in "manipulative conduct to profit on RBS's significant derivatives and money market trading positions” (CFTC RBS, 2013, p. 4).

"UBS had no systems, controls or policies governing the procedure for making LIBOR submissions” (FSA, 2012c, p. 5).

Opportunities and Temptations "Barclays had no (or inadequate) systems and controls that related specifically to its LIBOR...setting processes during the Relevant Period. There were several relevant opportunities for Barclays to review its systems and controls; however, Barclays did not carry out any review on these occasions” (FSA, 2012a, p. 34).

"RBS created an environment for a number of years that eased the path to manipulation in as much as RBS sat derivatives traders and submitters together on the same desk, heightening the conflict of interest between the profit motives of the traders and the responsibility of submitters to make honest submissions. When derivatives traders and submitters eventually were separated ..., the misconduct continued through Bloomberg chats and an internal instant messaging system rather than by one trader merely turning in his chair to speak to his colleague on the desk” (CFTC RBS, 2102, p. 2).

“A number of UBS managers knew about and in some cases were actively 


\section{Context}
Context of action

involved in UBS's attempts to manipulate LIBOR ...submissions. In total, improper requests directly involved approximately 40 individuals at UBS, 11 of whom were Managers. (FSA, 2012c, p. 5).

"By the end of 2010, the Primary Submitter became sufficiently cautious to feign refusal of a written request of the Senior Yen Trader for a false LIBOR submission, only then to promptly telephone and assure his cohort that he was only playacting on the chat to avoid detection, and would follow through on the request” (CFTC RBS, 2012, p. 30).

"Management directive impacted at least Barclays' U.S. Dollar LIBOR submissions in multiple maturities ("tenors") on a regular basis throughout the financial crisis period (CFTC Barclays, 2012, p. 4).

"We have another big fixing tomorrow and with the market move I was hoping we could set the 1M and 3M Libors as high as possible" (CFTC development Barclays, 2012, p. 9). "Could really do with a low 1m over the next few days as have $17.5 \mathrm{~m}$ fixings if ok with you" (CFTC UBS, 2012, p. 14).

Request was meticulously developed and requested: "Hi ... can we go low lm and 3m again pls" was met with response "We'll try ... but there's a limit on to how much [w]e can shade it i.e. we still have to be within an explainable range” (CFTC UBS, 2012, p. 17).

“On a regular basis, UBS's Swiss Franc Trader-Submitters adjusted UBS's Swiss Franc LIBOR submissions to benefit UBS's trading positions. The Swiss Franc Trader-Submitters' standard practice was to round their Swiss Franc LIBOR submissions by a quarter or a half of a basis point to benefit UBS 's net Swiss Franc LIBOR This was known on the desk as the "fixing interest" (CFTC UBS, p. 38).

"The conduct of the dozens of Derivatives Traders and Trader-Submitters occurred openly and was pervasive at UBS on certain trading desks, even involving the participation or knowledge of desk managers and senior managers... The Senior Yen Trader, directly or indirectly, made at least 800 requests in writing, on UBS's email and chat systems, to the TraderSubmitters for adjustments to UBS's Yen LIBOR submissions, usually focused around the one, three and six-month tenors” (CFTC UBS, 2012, p. 6 7 17).

\subsection{Data Source 2}

\subsubsection{Written Evidence and Transcripts from PCBS Hearings}

To supplement the cases, I used the written evidence and transcripts from witnesses' examinations taken before the PCBS between June 2012 and March 2013. The PCBS was appointed by both Houses of Parliament to conduct an investigation into the professional 
standards and culture of the financial services sector. To gain insight into the data, I divided the research process into three phases.

In phase one, I attempted to map the data in order to secure an understanding of the contours and relational complexities of the financial industry in general. I particularly focused on the nature of the industry, the rules governing financial institutions and the enforcement of these rules. The discussion on the evidentiary thresholds, prosecutorial difficulties and the moral context (weak enforcement of rules) presented earlier is part and parcel of the result of this mapping.

In phase two, I undertook a review of the oral and written evidence provided to the PCBS. I used the final report as a starting point. Since the PCBS inquiry conducted public hearings involving 733 witnesses and a vast amount of documentary evidence, including the transcripts and oral and written evidence from the witnesses, the final reports provided a good synopsis of the major themes addressed in the inquiry. Written and oral evidence from the PCBS hearings was collected from the following Panels:

- Panel on Financial Exclusion and Basic Bank Accounts

- Panel on mis-selling and cross-selling

- Panel on regulatory approach

- Panel on tax, audit and accounting

- Panel on Scotland

- Panel on corporate governance: board level

- Panel on the operation of wholesale markets

- Panel on retail competition

- Panel on corporate governance: below board level

- Panel on HBOS

- Panel on the consumer and SME experience of banks

The transcripts of oral and written evidence are available to the public and were collected from U.K. Parliamentary Archives. Between June 2012 and March 2013, the PCBS held over forty public hearings and received copious amounts of both written and oral evidence from 
professors, former and present members of parliament, bankers, regulators, senior bureaucrats, accounting firms, standard setters and advocates regarding financial crime prosecution and implications for regulatory reforms and Government policy. The materials reviewed included written and oral evidence from the Big Four accounting firms, the major accounting bodies in the U.K. (ACCA and ICAEW), as well as all major government reports. The accounting and audit evidence was of particular interest as the witnesses recognised the risks of the increasingly complex accounting requirements surrounding IFRS and the concerns that the framework is not fit for regulatory purposes. The financial resources available to the PCBS - about £850,000 was devoted to the inquiry - allowed the Commission to undertake background research of suitable witnesses and conduct a wide-ranging set of hearings. Thus, the available testimonies, as well as the other supporting documents, are more in-depth than anything that a single researcher could have collated.

In the third phase, I examined the oral and written evidence in much more details. The oral and written evidence gathered from all volumes of the PCBS hearings totalled approximately 4, 418 pages of transcripts, commentaries and expert opinions on financial crime and regulation. The materials were collected and stored on a back-up drive. I then went through the materials and developed a list of thematic categories central to the tenets of SAT. After the categories were identified, I then reviewed them and made further refinements. This theorydriven and iterative methodology was applied throughout the research and writing process. The subsequent analysis is coalesced around these theoretically-informed categories. The oral and written evidence included questions about the prevailing culture of misconduct and the problems experienced by authorities in investigating and prosecuting financial misconduct in the U.K. The 
evidence gathered by the PCBS provided an excellent opportunity to examine the application of SAT to financial fraud.

\subsection{Data Source 3}

\subsubsection{Responses to the Reports}

I also used the responses of the HM Treasury, the FCA and the Bank of England to the PCBS's final report because they provide greater insights into the problems associated with prosecution and recommended policy reforms. The FCA in particular made references to collective decision-making in corporate settings and the peer influence that characterises fraudulent conduct in the financial sector. Welcoming the findings of the Report, these regulatory agencies in their responses recognised that there is a relationship between criminogenic corporate environment and weak enforcement sanctions. The responses from regulators serve as clarifications for the argument on peer influence (i.e., erosion of collective standards) in fraudulent conduct and, more importantly, as evidence to corroborate the claim that crime tends to occur when there is a convergence of crime-prone individuals and contextual factors that are favourable to crime.

Altogether, the materials provide rich insights into the genesis of factors that influence people's propensity to engage in financial fraud and the emergence of their exposure to structural settings with features that encourage acts of fraud. The cases and written evidence and transcripts from the PCBS Hearings provide sufficient information to carry out an informed analysis of the contextual and prosocial factors that influence the processes that move people to engage in acts of crimes. The reactions of regulators are of interest because they address a wider problem associated with financial crimes; that is, the criminogenic environment in which such crimes occur and the realistic prospect of enforcement actions for individuals whose action alternatives 
are to circumvent regulation. Table 3 below provides a summary of the data sources and their

uses.

Table 3: Organisation of Data Sources

\begin{tabular}{|c|c|c|c|}
\hline & Sources of Data & Description & Primary Purpose \\
\hline \multirow{3}{*}{ Cases } & $\begin{array}{l}\text { Annual Reports and } \\
\text { Financials }\end{array}$ & $\begin{array}{l}\text { Cattles plc. } \\
\text { financial data } \\
\text { from } 2007 \text { to } \\
2009 ; \text { LIBOR } \\
\text { banks financial } \\
\text { analysts' data } \\
\text { from } 2005 \text { to } \\
2010 .\end{array}$ & $\begin{array}{l}\text { Develop an understanding of the financial } \\
\text { performance of the entities for the periods under } \\
\text { investigation; develop an understanding of } \\
\text { accounting and audit standards (moral rules); } \\
\text { develop an understanding of how the entities } \\
\text { responded to regulatory requirements; develop an } \\
\text { understanding of control mechanisms in place to } \\
\text { mitigate fraud. }\end{array}$ \\
\hline & $\begin{array}{l}\text { CFTC Hearing } \\
\text { Orders }\end{array}$ & $\begin{array}{l}\text { Transcripts from } \\
\text { regulatory } \\
\text { gearings. }\end{array}$ & $\begin{array}{l}\text { Develop an understanding of the behaviour of } \\
\text { individuals involved in the fraud; strengthen } \\
\text { insights into corporate settings and environment } \\
\text { of fraud; understand corporate culture and } \\
\text { incentivisation techniques. }\end{array}$ \\
\hline & FSA Hearing Notices & $\begin{array}{l}\text { Notices from } \\
\text { regulatory } \\
\text { hearings. }\end{array}$ & $\begin{array}{l}\text { Further strengthen the evidence of individuals' } \\
\text { behaviour from the Orders; develop an } \\
\text { understanding of the impact of financial } \\
\text { innovations and culture; understand the nature of } \\
\text { the offences; understand the enforcement of moral } \\
\text { rules. }\end{array}$ \\
\hline $\begin{array}{l}\text { PCBS } \\
\text { Hearings }\end{array}$ & $\begin{array}{l}\text { Written and oral } \\
\text { evidence }\end{array}$ & $\begin{array}{l}\text { Written evidence } \\
\text { and transcripts of } \\
\text { oral witnesses to } \\
\text { the PCBS } \\
\text { committee. }\end{array}$ & $\begin{array}{l}\text { Collect first-hand information from bankers, } \\
\text { accountants, regulators, members of parliament } \\
\text { and professors on the culture, contextual features } \\
\text { and environmental characteristics of financial } \\
\text { fraud; develop an understanding of individual } \\
\text { behaviours (propensity) and enforcement (moral } \\
\text { context) in the financial sector. }\end{array}$ \\
\hline $\begin{array}{l}\text { Government } \\
\text { Responses }\end{array}$ & $\begin{array}{l}\text { Reports issued by } \\
\text { government and } \\
\text { regulators }\end{array}$ & $\begin{array}{l}\text { Responses from } \\
\text { the HM Treasury, } \\
\text { FCA and Bank of } \\
\text { England to the } \\
\text { recommendations } \\
\text { of the PCBS. }\end{array}$ & $\begin{array}{l}\text { Understand the nature of fraudulent conduct by } \\
\text { market participants; understand the responses by } \\
\text { regulators for fraudulent conduct; understand the } \\
\text { normative expectations and cultural practices of } \\
\text { market participants; understand corporate legal } \\
\text { framework and criminal law. }\end{array}$ \\
\hline
\end{tabular}

\section{Analysis: Application of SAT}

In applying SAT, the focus will be on an analysis concerning the causes of the acts of

financial fraud and to establish a foundation that standard setters can use to inform fraud

detection and prevention strategies. The tenets and diagrammatic illustrations of SAT in Figure 1 
present an explanation that considers both the individual and environmental factors that lead to

financial fraud. The fundamental assumptions in the application of SAT are as follows:

1. Individuals' involvement in crime depends on their crime propensity (i.e., moral values and ability to exercise self-control) and the interplay with their exposure to a criminogenic moral context (i.e., moral rules and level of enforcement);

2. Individuals engage in crime because of a perception-choice process that comprises of two stages: (1) they come to see such action as a viable alternative in response to a particular motivation; and (2) the process of choice to choose (habitually or deliberately) to commit such acts; and

3. The environment and contextual factors influence criminogenic behaviour.

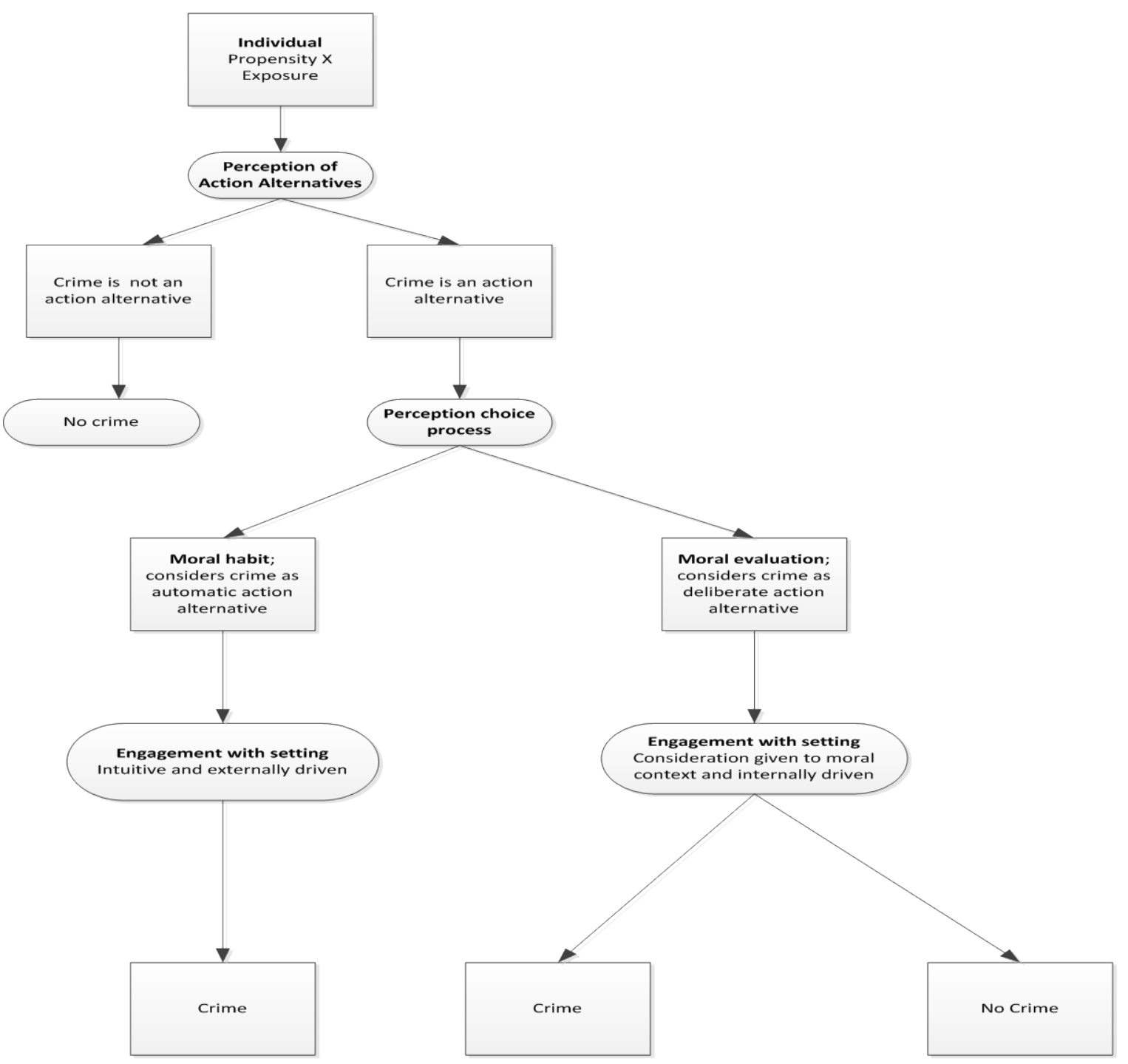

Fig. 1: Diagrammatic illustration of the Application of SAT to Financial Fraud 


\subsection{Assumption 1: The Individual Crime Propensity and Criminogenic Exposure}

SAT proposes that individuals vary in their propensity to commit acts of crime because of their morality and their capability to exercise self-control (Wikström, 2015, p. 256). Crime propensity is the tendency to choose acts of crime as a viable action alternative in the face of motivation (i.e., temptation and provocation) to offend (see Dacin \& Murphy, 2011; Free \& Murphy, 2013; Murphy, 2012). Exposure to a criminogenic setting is thus crucial to our understanding of how individuals develop a propensity to become involved in criminogenic activities (see also Cooper et al., 2013; Free \& Murphy, 2013; Lokanan, 2015a; Morales et al., 2014).

This general reasoning is applicable to financial fraud. Directors who over the years have developed a propensity to work with external auditors to manipulate their companies' financial statements may rationalise this conduct and not see any problem in doing so (Bishop, DeZoort, \& Hermanson, 2017; Free \& Murphy, 2013; Lord \& DeZoort, 2001; Murphy, 2012; Murphy \& Dacin, 2011; Murphy \& Free, 2016). In the Cattles case, the directors’ moral action (to manipulate the financial statements) and action alternative to breach a moral rule (IFRS 7) are framed and mobilised in the accounts to the PCBS as critical markers of the box-ticking culture that characterises the industry. The extent to which this enhances and presupposes a trend of normalisation is evident in a number of accounts. In written evidence submitted to the PCBS on tax, audit and accounting, Professor Stella Fearnley (Bournemouth University) and Professor Shyam Sunder (Yale School of Management) noted that:

Research by Beattie, Fearnley and Hines ${ }^{3} \ldots$ indicates that finance directors, audit committee chairs and auditors of UK listed companies felt that the change in the regime both for accounting, auditing and enforcement had led to a compliancedriven box-ticking environment. This had changed significantly from the previous

\footnotetext{
${ }^{3}$ For a detailed discussion on this issue, see Beattie, Fearnley, and Hines (2011) on financial reporting decision and interaction between directors and auditors.
} 
regime and had been driven by: (1) a more rigorous post-Enron enforcement regime including the introduction of audit inspection and the more pro-active role taken by the Financial Reporting Review Panel; (2) the introduction of International Standards of Auditing (ISAs) by the UK Auditing Standards Board with more detailed set of requirements; and (3) IFRS (PCBS, 2013i, p. H Ev 87).

In a similar manner, Professor Prem Sikka from Essex Business School adopted the position that the box-ticking mentality involves exposure to moral teachings which individuals adopt as their own:

The tick-box mentality is deeply embedded in accounting and auditing practices. It is encouraged by professional education. Accounting firms see the tick-box approach as a way of increasing efficiency i.e., the necessary tasks have been performed. Partners performing reviews of audit cannot replicate the field work to see that the necessary task have been carried out. The size and order of the file and related schedules rather than the quality of work impresses partners (PCBS, 2013i, p. H Ev 151).

Professor Sikka went on to argue that "in this environment, IFRSs have further deepened a tickbox approach as accounting standards are often presented in a formulaic way” (p. H Ev 151).

The FSA further noted a tendency by "auditors to take a narrow, box-ticking approach of assessing whether transactions are 'clearly inconsistent with accounting standards' rather than applying professional skepticism”” (PCBS, 2013b, p. 156).

In contrast and by virtual opposition to the aforementioned accounts, the Big Four accounting firms held firm in the strength they attached to action relevant moral rules (i.e., IFRS) and their shared experience in their setting:

\section{Deloitte}

No. We do not believe that IFRS accounting standards contributed to a "tick box" culture to the exclusion of promoting transparency and a "true and fair view" of the business. IFRSs are principles-based. Contrary to the box-ticking mentality, they require significant exercise of professional judgement by both preparers and auditors (PCBS, 2013i, p. H Ev 263). 


\section{KPMG}

We do not believe that the IFRS accounting standards contributed to a box ticking culture. On the contrary, we believe that IFRS improved transparency compared to pre 2005 UK GAAP accounting for financial instruments. However, we do think that its introduction coincided with a period of time, when the approach of preparers and regulators was simply to provide the markets with ever increasing amounts of data on the basis that they would absorb and interpret them themselves (PCBS, 2013i, p. H Ev 304).

\section{PricewaterhouseCoopers LLP (PwC)}

IFRS is a principles-based accounting framework that requires judgments to be given careful thought and consideration. It does not reduce the need to exercise judgment or to provide transparent information (PCBS, 2013i, p. H Ev 123).

\section{Ernst and Young}

No. The relevant literature demonstrates that IFRS is generally more prescriptive and detailed than UK GAAP. An example would be the rule that an entity may not recognise a 'day one' profit when it first enters into a financial instrument, if all the inputs required to value that instrument are not observable in an active market. However, like UK GAAP, IFRS is a principles-based set of accounting standards that require the application of judgement and professional experience by auditors when auditing financial statements prepared by directors (PCBS, 2013i, p. H Ev 186).

Although a setting's moral context is shaped by other stakeholders (e.g., regulators, accounting bodies, investors’ advocates etc.), in this case, the accounting firms and their peers proved particularly influential in the measure of the strength they attached to a moral rule (e.g. see. Chung, Farrar, Puri, \& Thorne, 2010; Cortese, Irvine, \& Kaidonis, 2010; Humphrey, Loft, \& Woods, 2009; Knechel \&Vanstraelen, 2007).

The accounting firms, despite evidence of accounting malfeasance, clearly invested in a broader set of scripts regarding the value-added effectiveness of accounting standards (e.g. see Dellaportas, 2013; Lokanan, 2015a; Morales et al., 2014; Sikka, 2010, 2015). Framed as deviation and aberration from standard accounting practices, these opposing accounts are then accompanied by very different versions of the requisite regulatory responses from the 
professional accounting bodies. The Institute of Chartered Accountants in England and Wales

(ICAEW), in written evidence to the PCBS, remains wedded to a conception that the assemblage

of rules and their interpretation lies in their details and sound professional judgement:

IFRS accounting standards include more detailed rules than previously existed under UK generally accepted accounting principles (GAAP). This detail has grown largely in response to concerns raised about various accounting practices and is intended to increase transparency. We support principles-based standards, which require the exercise of professional judgement, but if too much is left to judgement, it can lead to inconsistency and suspicions that it allows so-called “creative accounting” (PCBS, 2013i, p. H Ev 93).

Following closely on the heels of these attributional discourses, the ICAEW's stance was similarly articulated in terms of efficiencies and application by the Association of Chartered Certified Accountants (ACCA), which serves to reaffirm the naturalness and normalcy of IFRS rules:

As with all accounting standards there is a degree of risk that people will choose to apply them in a literal way. IFRS amounts to an extensive set of requirements and disclosures and so some preparers may have more readily adopted that attitude. Overall however we consider that the adoption of IFRS has improved and promoted transparency in financial reporting and not diminished it (PCBS, 2013i, p. H Ev 93).

Admittedly, these accounts are characterised by various juxtapositions and competing interpretations of both compliance with moral rules and the preferred regulatory responses. The struggles, as they are manifested, are neither inconsequential, nor are they mere issues of interpretative nuances. Far from such framing, they reflect real differences in how the rules are conceptualised and the underlying modes of legitimisation attributed to their values and effectiveness in criminogenic settings (Cohen et al., 2010; Farber, 2005; Gabbioneta et al., 2013; Murphy \& Dacin, 2011).

Despite this semantically porous position and contradictory meanings and interpretations by the accounting establishment, there is a broader set of scripts that are coalesced around the 
rules as they are enacted and the level of enforcement attached to them (i.e. moral context).

Couched in the analytics of de-criminalisation (e.g. see Sikka, 2008, 2015; Samsonova-Taddei \& Humphrey, 2015), various accounts presented to the PCBS argued that rules and codes put in place to safeguard the public interest from financial fraud has been a "failure" because there "has been no enforcement" and "governments have opted for softer options rather than investigation, enforcement and punishment” (PCBS, 2013i, p. H Ev 146). This juxtaposition of normality and aberration is tied to actual enforcement strategies of regulatory agencies tasked with safeguarding the market:

It is notable that the existing professional standards bodies ...have to date failed to make use even of what limited enforcement action is already within their powers_-removal of membership (PCBS, 2013a, p. 302).

There has been a culture of impunity at the highest level in the regulation of financial services in that criminal fraud has been alleged but no action taken by either the FSA or the Serious Fraud Office (SFO). It would seem that above a certain level individuals are exempt from the ordinary processes of the criminal law (PCBS, 2013e, p. Ev 815).

These points of complementarities and naturalisation of lax enforcement lend themselves to a variety of analytical pathways and calculative actions (Dorminey et al., 2012; Murphy \& Dacin, 2011; Power, 2013):

What tends to happen is that the institutions get a fine that can look large in terms of the initial sum of money but, compared with the profits they make every year or their turnover can actually be absorbed by them as the cost of doing business. It is very rare that individuals get fired, punished, sent to jail or whatever (PCBS, 2013d, p. Ev 49).

While petty frauds, clumsily committed, are likely to be detected and punished, it is all too likely that the largest and most cleverly executed crimes escape unpunished” (PCBS, 2013e, p. Ev 1079).

All of this is to suggest that cultures with poor collective adherence to norms and favourable regulatory responses to market actors are neither inconsequential nor are they mere matters of 
legislative nuances; they reflect very real enforcement issues that aid fraudulent behaviour (e.g. see Bank of England, 2013; HM Treasury, 2013; PCBS, 2013g).

\subsection{Assumption 2: The Action Alternative and Perception-Choice Process}

The perception of action alternatives implies that the actor considers two options in the choice process: to see crime as an action alternative or not to see crime as an action alternative. Perception of choice processes to satisfy a motivation and consider an act of crime can be deliberate or by habit without giving it much thought i.e. the action is habitual (Hirtenlehner \& Hardie, 2016, p. 317, emphasis added). In cases where the choice process is deliberate to a particular motivation, the resultant effect can be crime or no crime (Wikström, 2015, p. 17). However, in cases when people act out of habit, they perceive only one action alternative and automatically form the intention to carry it out (Hirtenlehner \& Hardie, 2016, p. 317).

\subsubsection{Rational Deliberation}

The rules and practices relating to a setting can have a huge impact on rational deliberation. With many incentives linked to the fair value attributed to financial instruments, market actors can be rational (not necessary immoral) in the pursuit of profit (Cooper et al., 2013; Murphy, 2012; Murphy \& Free, 2016; O’Connell, 2004). In the Cattles case, where rational deliberation is concerned, an implicit form of intelligibility and knowledgeability of circumventing the rules governing financial crimes were invoked. For the first time in 2007, Cattles’ Annual Report was required to be prepared in accordance with IFRS 7. IFRS 7 specifically deals with risks and the management of those risks. In particular, IFRS 7 paragraph 31 stated that companies should "disclose information that enables users to evaluate the nature and extent of risks arising from financial instruments to which the entity is exposed”. Numerous meetings were held with Cattles’ directors, PwC and the Audit Committee to determine whether 
deferments should be disclosed as renegotiated loans or as past due loans under IFRS 7 and the effect they would have on Cattles' books. In the end, Cattles directors concluded that deferments should not be classified as renegotiated or past due because it would mean that a significant portion of the loan book would be seen by analysts as either renegotiated or as past due and disclosure of these would provide negative information about the credit quality of Welcome's loan book.

The particular logic inherent in the directors' actions is far from passive and by no means accidental. Rather, it is accorded an intelligibility informed by a broader purported rationality (PCBS, 2013d, p. Ev 434) that is rooted less in trigger points and their relative sensitivities vis-àvis different forms of (mis)conduct (Williams, 2013), and more in specific taken-for-granted assumptions regarding the applications of accounting rules and principles (Bell \& Carcello, 2000; Gabbioneta et al., 2013; Stalebrink \& Sacco, 2007). Figure 2 below shows the original figures Cattles reported in its 2007 Annual Report for Welcome under IFRS 7 impairment disclosures compared to the correct and restated figures Cattles reported in its restated 2008 Annual Report. When comparing the two Reports, it is evident from Figure 2 that Cattles give a false and misleading picture of its credit quality. As a result of the adjustment, Cattles made a loss of £96.5 million rather than a pre-tax profit of £162.2 million, as stated in its 2007 Annual Report. 


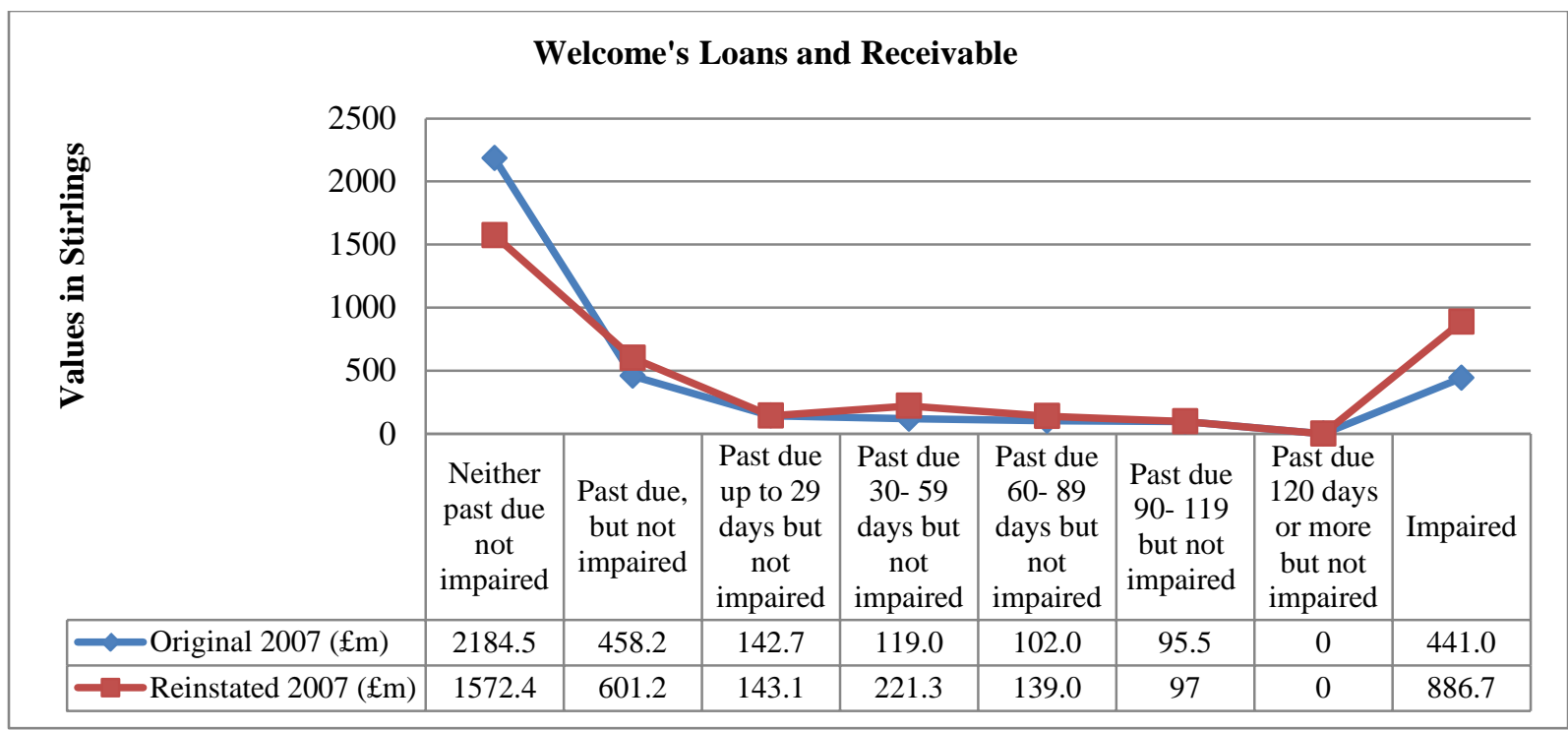

Fig. 2: Welcome Credit Quality

These irregularities suggest that, despite the implicit forms of intelligibility invoked, the directors deliberately made a moral judgement to be complicit in signing off on the veracity of Welcome’s financial statements, which they knew to be false and misleading. Deliberation would imply that the directors (given the credit quality of Welcome) considered several options (that may include not manipulating the financial statements) but decided to choose an action alternative that appeared best to them (e.g. Carcello \& Nagy, 2004; DeFond \& Francis, 2005; Dellaportas, 2013; Rezaee, 2005). By deliberating the implications of their competing action alternatives - that is, to treat the defer loans as contractual arrears and incur a pre-tax loss of $£ 96.5$ million or chose not to disclose the use of deferments and make a pre-tax profit of $£ 165.2$ million - the directors made a rational choice about which course of action to pursue (e.g. Albrecht et al., 2004; Beasley, Carcello, Hermanson, \& Lapides, 2000; Brennan \& Conroy, 2013; Dechow, Sloan, \& Sweeney, 1996; Erickson, Hanlon, \& Maydew, 2004; Rezaee, 2002). While some failings can be explained by references to etiological clusters of executive wrongdoings and manipulation of financial statements, other accounts of financial fraud provide 
a window of the interpretive devices through which deliberate and rational deception have been normalised and valorised for personal gain. As troubling as the manipulation of the LIBOR rates was, the reference point that captures the imagination is how the setting determines the action alternative of the individuals involved through a deliberate choice process:

Derivatives Trader B: can we lower our fixings today please [Primary Submitter B] Primary Submitter B: make your mind up, haha, yes no probs Derivatives Trader B: im like a whores drawers Primary Submitter B: hehehe, mine should remain flat, always suits me if anything to go lower as I rcve funds

Broker B: gotcha, thanks, and, if u cud see ur [sic] way to a small drop there might be a steak in it for ya, haha Primary Submitter B: noted ;-)

Trader G: “Dude. I owe you big time! Come over one day after work and I’m opening a bottle of Bollinger".

Euro Trader-Submitter 1: u need low 3s and/or 6s? we need low 6s ... boys, we send the fixings in about $1 \mathrm{hr}$, so let us know pls

Euro Trader 1: low 6s high 12s please

Euro Trader-Submitter 1: Noted

Rates Manager A: JUST BE CAREFUL DUDE

Euro Trader-Submitter 1: yeah [Sterling Trader-Submitter 1] gave me ur call update i agree we shouldnt ve been talking about putting fixings for our positions on public chat just wanted to get some transparency though otherwise we end up with the same talks afterwards why we fixed it low or high, from u boys in ldn (PCBS, 2013a, Pp.99-100).

Anthony Salz, the lawyer-turned-Rothschild investment banker, in his independent review of banking culture and practices at Barclays noted that these communications "seemed to confirm a pervasive, much-caricatured, unethical, greedy and selfish behaviour on the trading floors of investment banks” (PCBS, 2013a, p. 100). They paint a picture of the LIBOR rates as objects that can be manipulated by individuals who are exposed and respond in particular ways to address a desire, motivation or a source of friction (e.g. Jones, 2011; Lehman \& Okcabol, 2005;

Sikka, 2015).

\subsubsection{Habitual Action}


In the case of habit, SAT posits that the actor perceives only one action alternative (the act of crime) and automatically forms the intention to carry it out (Wikström, 2015, p. 19). During the LIBOR scandal, habituation (or repeated exposure) to a criminogenic setting facilitated a choice process where the traders and managers involved saw only one action alternative to address a source of friction- rig the interest rates - "to get in line with the competition” (FSA Final Notice to UBS, 2012c, p. 26). Rigging the LIBOR rates was an “industry-wide practice" (CFTC UBS, 2012) that functioned to perpetuate and sustain certain beliefs and practices that are critical to the normal functioning of the LIBOR:

I don't know if you've looked at my libors but I've kept mine the same virtually every day for the last week and everyone seems to be gradually sort of coming up to my levels, and I can tell you that I'm putting levels in that I' m not sure I can trade or not, but I know they're more realistic than anyone else's (Libor Transcripts, 2008, Conversation with Trader).

The Treasury Committee's Report on Fixing LIBOR noted "that there can also be a culture, in some parts of a universal bank, of breaking regulation” (PCBS, 2013e, EV 887). For example, the CFTC’s regulatory investigations of Barclays conduct documented many conversations which indicated that the traders and submitters at the banks knew they were involved in illegal activities, but still perceived such activities to be normal:

Multiple traders engaged in [manipulating the rates], and no attempt was made by any of the traders to conceal the requests from supervisors at Barclays during the more than four-year period in which the activity occurred. In fact, traders would often shout across the trading desk to fellow traders to confirm there were no conflicting requests before they sent their requests to... submitters, and, on occasion, the traders discussed their requests with trading desk managers (CFTC Barclays, 2012, p. 8).

Consistent with the culture at Barclays, the CFTC's inquiry into the conduct at UBS found that manipulation was an almost daily occurrence among traders and managers: 
The Senior Yen Trader, directly or indirectly, made at least 800 requests in writing, on UBS's email and chat systems, to the Trader-Submitters for adjustments to UBS's Yen LIBOR submissions, usually focused around the one, three and six-month tenors. The conduct of the dozens of Derivatives Traders and Trader-Submitters occurred openly and was pervasive at UBS on certain trading desks, even involving the participation or knowledge of desk managers and senior managers (CFTC UBS, 2012, p. 12).

In each of these respects, we are again in familiar territory: the decision-making process falls back on habitual behaviour that requires little or no deliberation (e.g. Bell \& Carcello, 2000; Bishop et al., 2017; Free \& Murphy, 2013); but, also the actors are reacting to cues or stimuli that reward them to pursues one action alternative (Murphy, 2012).

The most striking feature of these conditions of existence is manifested in the way the LIBOR fraud was allowed to prolong itself because of the long-term neglect and negligence on the part of gatekeepers tasked with safeguarding the financial markets (Bank of England, 2013; HM Treasury, 2013). The scandal started in 2005 and continued undetected until 2008. Judging by appearances, it seems as though rigging the rates was a case of business as usual (e.g., see Sikka, 2015). Those charged with safeguarding the financial markets were either oblivious or ignored the rate rigging that was taking place. As can be seen in Table 4, financial analysts and gatekeepers were still issuing positive recommendations to the stocks of the banks. Curiously enough, both Standard \& Poor and Moody’s had maintained investment grade ratings for these banks at the time the scandal was discovered. More importantly, the banks' external auditors added explanatory language to an unqualified opinion at some point during the four years of the scandal for Barclays and UBS and for all four years in the case of RBS. Similarly, no concerns were raised about the banks’ liquidity positions and internal control systems. In short, despite being audited by three of the Big Four audit firms, highly sophisticated rating agencies and 
financial analysts and, despite being under investigation by regulators, the banks were able to conceal their manipulation of the LIBOR for over four years.

Table 4: Assessment of Barclays, RBS and UBS by Financial Analysts and Gatekeepers

\begin{tabular}{|c|c|c|c|c|}
\hline & 2005 & 2006 & 2007 & 2008 \\
\hline \multicolumn{5}{|l|}{ Barclays } \\
\hline \multicolumn{5}{|l|}{ Financial Analysts } \\
\hline Buy & 10 & 6 & 13 & 13 \\
\hline Hold & 8 & 11 & 10 & 7 \\
\hline Sell & 5 & 3 & 4 & 6 \\
\hline Consensus recommendation & 3.39 & 3.3 & 3.7 & 3.54 \\
\hline \multicolumn{5}{|l|}{ Credit Rating Agencies } \\
\hline Standard and Poor & & & AA- & $\mathrm{A}^{+}$ \\
\hline \multicolumn{5}{|l|}{ Moody’s } \\
\hline \multicolumn{5}{|l|}{ Internal Control/Compliance } \\
\hline Legal proceedings (risk factors) & Yes & Yes & Yes & Yes \\
\hline Whistleblowing policies & Yes & Yes & Yes & Yes \\
\hline \multicolumn{5}{|l|}{ Auditors } \\
\hline \multicolumn{5}{|l|}{ PwC } \\
\hline Unqualified with additional language & Yes & Yes & & \\
\hline Unqualified & & & Yes & Yes \\
\hline \multicolumn{5}{|l|}{ RBS } \\
\hline \multicolumn{5}{|l|}{ Financial Analysts } \\
\hline Buy & 18 & 13 & 18 & 9 \\
\hline Hold & 5 & 7 & 8 & 10 \\
\hline $\begin{aligned} \text { Sell }\end{aligned}$ & 1 & 2 & 0 & 8 \\
\hline Consensus recommendation & 4.42 & 4.05 & 4.35 & 3.07 \\
\hline \multicolumn{5}{|l|}{ Credit Rating Agencies } \\
\hline Standard and Poor & & & & $\mathrm{A}+$ \\
\hline Moody’s & & & Aa1 & Aa2 \\
\hline \multicolumn{5}{|l|}{ Internal Controls/Compliance } \\
\hline Legal proceedings (risk factors) & No & No & No & Yes \\
\hline Whistleblowing policies & No & No & No & No \\
\hline \multicolumn{5}{|l|}{ Auditors } \\
\hline \multicolumn{5}{|l|}{ Deloitte \& Touche } \\
\hline Unqualified with additional language & Yes & Yes & Yes & Yes \\
\hline \multicolumn{5}{|l|}{ Unqualified } \\
\hline UBS & & & & \\
\hline \multicolumn{5}{|l|}{ Financial Analysts } \\
\hline Buy & 24 & 19 & 19 & 13 \\
\hline Hold & 6 & 7 & 8 & 15 \\
\hline
\end{tabular}




$\begin{array}{rrrrr}\text { Sell } & 1 & 0 & 2 & 7 \\ \text { Consensus recommendation } & 4.35 & 4.27 & 4.03 & 3.4\end{array}$

Credit Rating Agencies

Standard and Poor

Moody's

$\begin{array}{cccc} & & & \text { AA } \\ & & \text { Aa1 } & \text { Aa2 } \\ & & & \\ \text { Yes } & \text { Yes } & \text { Yes } & \text { Yes } \\ \text { Yes } & \text { Yes } & \text { Yes } & \text { Yes } \\ & & & \\ & & & \\ \text { Yes } & \text { Yes } & \text { Yes } & \end{array}$

Internal Controls/Compliance

Legal proceedings (risk factor)

Whistleblowing policies

Auditors

Ernst \& Young

Unqualified with additional language

Unqualified

Yes

Yes

At play in these representations is normal market functioning whereby a network of gatekeepers uncritically and unduly lost track of their monitoring functions, which opened up the gates for misconduct (Bank of England, 2013). Regardless, the symbolic value of the market persisted, despite the pervasive and entrenched manipulation of the global interest rates. While portraying the market as natural and autonomous, this process follows an ethic whereby habitual action is often normalised when people act in familiar circumstances (Anand et al., 2014; Cohen et al., 2010):

There were very large numbers of these wrongdoers, to use the least offensive word I can think of to describe them, and in fact it was the culture of the bank, was it not? There was an account in the FSA about a public chat group of some 58 people, in which one of the traders said, "Who would like me to fix LIBOR for them?” So everybody knew about it, everybody was in on it (PCBS, 2013d, Ev 324).

The perpetrators tend to follow the trend and do what others normally do in such circumstances without much thought (Ashforth \& Anand, 2003; Beneish et al., 2008; Macintosh, 2009; Murphy, 2012). This position of normality in the perception-choice process is represented in the following account by an oil trader:

No one is blaming them, but it is the culture of the bank. If, nothing to do with LIBOR, I happened to be looking at this chatroom because I was an oil trader and, 
therefore, I was interested in interest rates and what is going to happen to the US dollar, which is obviously relevant, and I picked up that somebody was offering to fix LIBOR for anybody, surely the culture of the bank should have meant that everybody who was looking at that would have thought, "Hang on a second." Indeed, one person did. Why did not all 75 people who were looking at that time pick it up and report it? (PCBS, 2013d, Ev 335).

Evidently, apart from the invocation of narrow clusters of stakeholders' interest, the traders and managers who were involved in the LIBOR rates fix did not consider their behaviour as wrong (CFTC UBS, 2012; HM Treasury, 2013). As a matter of fact, "they took it as the practice of the trade...this is how things operated, and it seemed harmless" (Vaughn, Finch, \& Tan, 2012, para. 4). Habitually breaching the rules governing market conduct presupposes a state of normality by the actors who remained couched in their views on the naturalness of financial markets notwithstanding that this view may have criminogenic elements (Cohen et al., 2010; Murphy, 2012).

\subsection{Assumption 3: The Environment and Contextual factors that Influences Criminogenic Behaviour}

The repeated references to culture in the accounts of financial frauds and the active complicity on the part of a variety of institutions and their players speak of a broader environmental and contextual problem of standards and compliance in the financial industry (e.g. see Bank of England, 2013; HM Treasury, 2013; PCBS, 2013a, 2013c). In fact, the entire

financial system is built on an institutional logic of systemic practices that interferes with the natural efficiencies of an inadequate and compromised regulatory apparatus (Beasley et al., 2000; Power, 2013; Williams, 2013). Various commentators who provided evidence to the PCBS used it as a sounding board to reinforce this point:

You were not holding the management of these organisations responsible for what was going on within these organisations. I take your point that you were not there when the enforcement decisions were made, but this evidence that has come from 
the FSA - that managers were not being held responsible - is a culture that was under your watch (PCBS, 2013d, p. Ev 365)

Other testimonies to the PCBS conceive fraudulent culture as an enduring feature of normal market functioning: "What I would say to you, first of all, is that the culture has been a problem" (PCBS, 2013d, p. Ev 210). There is a "cultural problem" in the financial sector that "sees rule books as raw materials for arbitrage” (PCBS, 2013i, p. H Ev 63). Other accounts made reference to the "whole culture [as being] rotten and therefore has to be dealt with at a regulatory level in a much tougher way than it has been” (PCBS, 2013d, p. Ev 332). Within these imputed forms, the accounts from the witnesses are seen as points of nodes that reveal a broader problem of noncompliance with regulation within the industry (Braithwaite, 2013; Sikka, 2015). The practice of enforcing violations is a normative enterprise (Williams, 2013) and a culture that is perceived to have poor collective adherence to rules and weak enforcement provides fodder for the very types of criminogenic behaviour that we have seen in the Cattles corporate accounting fraud and the LIBOR market manipulation (e.g. see Bank of England, 2013; HM Treasury, 2013).

The specific ambitions exhibited by these actors in their environment may suggest that agentive mechanisms are at play. In the Cattles case for example, the three directors were all experienced and had been in the financial industry for over ten years. Their combined industry experience enhanced their agency (i.e. they now had greater capacity to make happen the things they would like to see happen) in their current occupation (e.g. Brennan \& Conroy, 2013; Cohen et al., 2010; Gabbioneta et al., 2013). This perception allowed them to construct a setting favourable to criminogenic practices, which, in turn, interacted with an “environment” characterised by "the laxness of regulations”(PCBS, 2013h, p. C Ev 31), where "the probability of being caught and successfully prosecuted” remains weak (PCBS, 2013e, p. Ev. 823). 
As the following testimony suggests:

If risk and control functions cannot speak up and there is insufficient protection for risk functions, both in reporting line terms and otherwise, when you live in an environment in which company law drives directors for short-term profit you will end up with a risky...culture prone to fraud (PCBS, 2013g, B Ev 7).

These testimonies represent the basic storylines upon which the LIBOR fraud was conceived and allowed to prosper. The prevalence of greed, the systemic nature of market manipulation and the need for effective regulation were all part of an inchoate set of values regarding the nature, functioning and regulatability of the financial markets (Beasley et al., 2000; Gullkvist \& Jokipii, 2013; Williams, 2013).

Others see fraud in the financial sector as more systemic and facilitated by an inadequate and/or compromised regulatory apparatus (e.g. Davis \& Pesch, 2013; Power, 2013). For example, in the case of RBS, one of the issues cited in the evidence provided to the PCBS was that "there was a practice of submitters and traders sitting together” (PCBS, 2013d, p. Ev 653) and "not only [did they] share their views of market conditions, or 'market color' but they also told the submitter what their trading positions were and encouraged him to make submissions that would make their positions more profitable” (CFTC RBS, 2013, p. 6). This sensibility and contextualisation is evident in the testimonies to the PCBS:

In an environment where directors' duties are focused on short-term profit, if you do not have ...risk functions reporting outside of the executive-you will continue to have a risky...sector because they will focus on sales and profit (PCBS, 2013g, B Ev 9).

A combination of “increased opportunities” (CFTC RBS, 2013, p. 6) and “lack of regulatory prudence created an environment” (PCBS, 2013h, p. F Ev 105), where "hubris, poor risk controls and bad decisions” were able to establish themselves as the norm and, in many cases, 
representational devices for new standards of accounting and mainstream financial practices (PCBS, 2013c, p.H Ev 122).

The near ritualistic invocations of purported attributes that characterise the financial sector (as normal) provide an undeniable reality of systemic manipulation where deceit and illegal behaviour were allowed to flourish. Rigging the interest rates was routine "manipulation" (PCBS, 2013f, p. FR Ev 155) reinforced by the "swaggering, macho, somewhat nasty fraudulent [environment]" (PCBS, 2013a, p. 363) that "has gone awry" (PCBS, 2013f, p. FR Ev 64). Some testimonies to the PCBS even cited specific instances where individuals involved in fraudulent conduct “did not circumvent controls, as there were none in place” (PCBS, 2013d, p. Ev 351). UBS for example "had no systems, controls or policies governing the procedure for making LIBOR submissions” (Ev 338). This valorisation of legally sanctionable practices represents an observational lens, a kind of piercing into the veneer of the actions by the traders as neither “isolated episodes" (PCBS, 2013e, Ev 921), nor the actions of a few "bad apples ... that went unnoticed” (p. Ev 1396). Rather, the nefarious actions of the traders were conscious and directly influenced by a regulatory apparatus that allowed them to exhibit a "staggering lack of competence and an innate inability to accept responsibility” for rigging the interest rates (Ev 1396).

The forgoing analysis illustrates that the propensity of individuals to engage in financial crimes and the conditions of existence have their roots in a constellation of rules, conditions and logics of normalised distinguishability that are themselves constitutive of the culture of the financial industry. Individuals develop particular propensities to engage in financial crimes because of a reified sphere of activities operating according to moral rules coded in terms of boundaries, which allows them to see and choose crimes as viable action alternatives in 
particular circumstances (Williams, 2013). Market participants’ involvements in financial crimes are, ultimately, a consequence of how they see these options (i.e., reacting to the laws governing the financial sector) and make their choices (judgement or deliberation). In the final analysis, there is ample evidence to suggest that individuals who break the rules are exposed to experiences that make them susceptible (to crime-related) moral influences from the setting they are a part thereof. This follows a theoretical tack that action-relevant features of the setting are shaped and informed by pervasive contextual factors that contribute to the propensities of individuals to circumvent rules governing their behaviour (Cooper et al., 2013; Donegon \& Gagon, 2008; Gabbioneta et al., 2013; Neu et al., 2013b).

\section{Discussion and Concluding Comments}

The paper makes the case that financial fraud can be meaningfully and innovatively conceptualised as a moral action. A moral action is one guided by what an individual perceives as the right or wrong thing to do when a particular circumstance (opportunity) arises to commit crimes. In adopting this position, the paper presented an argument that both rational deliberation and habitual actions are themselves outcomes of the interaction between the individual and the environment - that is, the interaction between an individual's crime propensity and the moral context in which he or she operates. The moral contexts here are those in which individuals perceived there to be weak enforcement of action-relevant rules (i.e., the rules prohibiting financial fraud have been weakly enforced), aligned with specific concerns that are structured around thematic clusters, including: reform to accounting standards (Dorminey et al., 2012); additional criminal sanctions for financial crimes (Mitchell et al., 1998); more effective governance of the financial markets (Williams, 2013); and addressing the Machiavellian cultures

in organisations (Free \& Murphy, 2013; Murphy, 2012). Cast around the core themes that both 
individual and contextual factors are part of the causal processes of crime, the paper analysed financial crime from three fundamental assumption of SAT.

The first assumption pertains to an analysis that individuals' involvement in crime depends on their crime propensity and the interplay with their exposure to a criminogenic moral context. This aspect of the analysis, as it is framed and mobilised in both accounting and auditing research, has led to a compliance-driven adherence to rules that has become routinised and fails to consider the diversity of circumstances that companies experience (Braithwaite, 2013; Choo \& Tan, 2007; Power, 2013; Sikka, 2015). The routinisation of compliance is consistent with research towards the more general trend in accounting standards and financialisation in which the logic of assessment is applied in a formulaic way (Davis \& Pesch, 2013 ; Gabbioneta et al., 2013; Sikka, 2010). Within this imputed form of naturalness and normality, and in line with the critical accounting literature on the individual's choice to offend (Greve et al., 2010; Power et al., 2013; Cooper et al. 2013; Choo \& Tan, 2007; Power et al., 2013), people’s crime propensities are triggered into action by interacting with moral rules and levels of sanctions that exacerbate their moral vulnerability (Ashforth \& Anand, 2003; Lokanan, 2015b, Murphy \& Free, 2016; Ramamoorti, 2008). As was highlighted in various testimonies to the PCBS, circumventing these rules becomes part of the game (Braithwaite, 2013), in that they do not appear to be complex (Neu et al., 2013b), and, as such, the rule violation occurs on a routine basis (Ashforth \& Anand, 2013) and their enforcement becomes so taken-for-granted that they do not merit any serious attention (Williams, 2013; Sikka, 2015).

These complementarities bring to the fore the importance of moral context in analysing the perpetrators' conduct. In the analysis of the cases, it became apparent that the financial industry is animated by certain actions and the factor which determines whether or not a setting 
is criminogenic is the moral context that characterises that setting. The evidence from the LIBOR hearings, in particular, where senior managers instructed their subordinates and interacted with a setting of unwitting criminal conduct, confirms this point (Murphy \& Dacin, 2017). It is through this interpretive frame, informed by broader social and institutional logic, that the financial markets may be viewed as criminogenic and prone to fraud. This is not so much the skilful use of motives, interests and incentive structures, but, rather, one of knowledge and knowledgeability, where, as the findings revealed, the perpetrators are calculative in their actions because they know the prospect of criminal persecution is minimal and choose to maximise their net utility through criminality for personal gain (Davis \& Pesch, 2013; Morales et al., 2014; O’Connell, 2004; Ramamoorti, 2008; Rezaee, 2005; Stalebrink \& Sacco, 2007).

The second assumption frame acts of financial crime as resulting from either a rational deliberation or a habitual choice process, which considers a criminogenic action as a viable action alternative. Here, the emphasis is on individuals' crime propensities and the moral norms of the financial setting, which may encourage or discourage breaking the rules governing the markets when acting on a particular motivation. As the forgoing analysis revealed, the most noteworthy aspects of the Cattles fraud and LIBOR market manipulation is not so much that they exposed the seedy underbelly of the financial markets, but that also they identified the calculative practices that were at play in various conventional techniques and scenarios (Murphy \& Dacin, 2011; Mayhew \& Murphy, 2014). In situations where individuals were confronted with opportunities to violate rules governing the industry, executives and traders who were experiencing financial loss or were in losing positions, chose action alternatives that were criminogenic. These findings are regularly implicated in a key strand of the accounting literature reviewed that promoted a discourse of financial fraud as, not only related to defects in 
individuals' frail morality, but also to complex environmental factors and a breakdown of organisational controls; both of which combined and contributed to action alternatives that were criminogenic in nature (Davis \& Pesch, 2013; Donegan \& Gagon, 2008; Morales et al., 2014; Power, 2013;). This view of what seems like a natural reckoning fosters a climate wherein choices are understood to be facilitated by the exercise of agency (i.e., the individual's ability to engage in financial crime) within rule-guided constraints (Murphy, 2012; Murphy \& Free, 2016).

Crucially, the formation of intention to engage in financial criminality and satisfy motivations were, in some instances, guided by habit (i.e., without much thought). As was discussed in the analysis, the perpetrators who acted out of habit were reacting to environmental cues that encouraged criminogenic behaviour. These findings highlighted the point made in previous research that habitual actions are the results of the perpetrators' repeated exposure to structural features of settings that are themselves conducive to financial criminality (i.e., being automated, see e.g. Choo \& Tan 2007; Cooper et al., 2013; Dorminey et al., 2012; Gabionetta et al., 2013; Hogan et al., 2008;). To the extent that financial crime is examined as the object of analysis, this position is materialised in a series of both conceptual and empirical studies, themselves constituted through interpretive frames and accorded an intelligibility by the wider logics of socialisation whereby individuals are said to learn from past experiences (of success and failure) and observed consequences of sanction severity to guide their automated choices (Beneish \& Vargus, 2002; Dechow et al., 1996; Delaportas, 2013; Free \& Murphy, 2013). While there is no doubt about the complexity of these decisions, a critical understanding of financial markets, corporations and criminality rests on the belief that habitual criminogenic choices are more likely when the individuals are in familiar territory, that is, they are aware of the culture, the rules and codes governing behaviour, and enforcement outcomes. 
The third assumption posits that acts of crime can be seen as a causal interaction between a person's crime propensity and his or her exposure to environmental inducements that encourage criminogenic behaviour. As explored earlier, the criminogenic features of the financial industry are attributed to the rules governing the industry and their level of enforcement in relation to the opportunities they provide and the frictions they generate. Explanations of this purported rationality should not only be sought in the psychological traits of the individual offender (crime propensity); but, also, in the wider social, political and economic contexts, as well as the operational contingency (criminogenic exposure) of the setting. These points of complementarity are undergirded by a larger diagnostic strand of literature that is wedded to a conception of fraud as the outcome of a process of transmission, which is aligned with the cultures, codes and customs of settings with criminogenic features (Beasley et al., 2010; Donegan \& Ganon, 2008; Gabbionetta et al., 2013; Mitchell et al., 1998; Stuebs \& Wilkinson, 2010). In a setting characterised by executive greed (as in the Cattles fraud), systematic manipulation (as in the LIBOR scandal), the view of the industry as one of profit maximisation and light-touch regulation has now become the normal functioning of the market and which have has crowded out concerns about ethics and morality (Sikka, 2015, p. 14; see also Ashforth \& Anand, 2003; Bishop et al., 2017; Murphy \& Dacin, 2011). It is in this much broader sense that the financial industry may be viewed as criminogenic and corroborates the findings of others that these types of scandals may reappear if the present conditions persist (Beneish \& Vargus, 2002; Braithwaite, 2013; Choo \& Tan, 2007; Donegon \& Gagon, 2008).

Although recent studies have shed light on the individualised and structural aspects of fraud (see Cooper et al., 2013; Lokanan, 2015a; Morales et al. 2014), they have not probed the routines of interaction, environmental context and collective behaviours and incentives that lead 
to fraud. Relying on data from cases, regulatory filings and testimonies, the present paper represents one of the few studies in the accounting literature that offers a unique contribution to understand financial fraud by merging the relational context of one type of crime to another in criminologically-related issues. It is in the recognition of this unique epistemology that the paper provides a number of interrelated contributions to the accounting literature on fraud.

Firstly, the paper extends previous work on fraud research in accounting by going beyond the need to understand individual's action from a micro-psychological or a macro-sociological perspective (Davis \& Pesch, 2013; Donegan \& Gagon, 2008; Lokanan, 2015a; Morales et al., 2014; Neu et al., 2013; Ramamoorti, 2008), to one that gives serious consideration for organising and interpreting causal factors as markers of financial fraud. Secondly, the paper takes into consideration the actions of the collective or groupthink as a form of financial intelligibility germane to financial crimes themselves. In fact, there is a lack of research that analyses the underlying dynamic of group behaviour in the critical fraud research in accounting (see Dorminey et al., 2010, 2012; Lokanan, 2014). This study is among the first to take stock of this gap to address the reified sphere of fraudulent activities and their manifestations in collective actions. Thirdly, the paper acts as a reference point on intervention efforts (Albrecht et al., 2004; Donegan \& Gagon, 2008; Gabbioneta et al., 2013) by providing a conceptual anchor to understand the relational connection ensuing from the organisation and its environment as the context and enactment of fraud (Davis \& Pesch, 2013; Gietzmann \& Pettinicchio, 2014; Power, 2013).

In general, it seems that there is scope for future research on financial crimes. Moving forward, critical accounting research must concern itself with a theoretical tack that seeks to define financial crimes as moral actions, using both micro-psychological and macro-sociological 
variables. This task is better left to interdisciplinary researchers who are encouraged to "sweep across the disciplines” (Braithwaite, 2000, p. 235) and incorporate insights from the sociology, criminology, legal studies, accounting and finance literature to the study of financial crimes (Williams, 2008, p. 493). Researchers must take stock of this theoretical stance with its distinctly interdisciplinary character and step outside the ontological box of one dimensional explanation that has long shaped the analysis of financial crime causation (see Cooper et al., 2013; Donegan \& Ganon, 2008; Lokanan, 2015b; Williams, 2013).

A good place to start this interdisciplinary inquiry is to undertake research that will expose the moral actions associated with financial criminality. By delving into the subterranean cluster of narratives on the moral actions of the perpetrators, researchers will be able to excavate the self-calculation and structural bases of the machinations that have come to characterise individuals involved in financial crimes (see Murphy, 2012). SAT can pave the way for innovative and integrated inquiries by opening up a broader discourse that addresses the individual and structural level variables associated with financial crimes. In this regard, SAT does not attempt to make concepts from different theories look more unified; rather, it considers the continuing development of different theoretical propositions germane to financial crimes themselves and instructive vis-à-vis to future fraud research.

\section{Reference}

ACCA. (2016). Fraud remains a growth industry, threatening companies large and small, but take heart: effective accounting practices can go a long way towards beating it. Retrieved from: http://www.accaglobal.com/za/en/member/member/accountingbusiness/2016/06/corporate/fraud-fight.html

American Institute of Certified Public Accountants. (AICPA). (2002). Statement on Auditing Standards (SAS) No.99.Consideration of Fraud in a Financial Statement Audit. American Institute of Certified Public Accountants, Durham. 
Albrecht, W. S., \& Albrecht, C. O. (2004). Fraud examination and prevention. Ohio: ThompsonSouthWestern.

Albrecht, W. S., Albrecht, C. C., \& Albrecht, C. O. (2004). Fraud and corporate executives: Agency, Stewardship and Broken Trust. Journal of Forensic Accounting, 5(1),109-130.

Albrecht, C., Holland, D., Malagueño, R., Dolan, S., \& Tzafrir, S. (2014). The Role of Power in Financial Statement Fraud Schemes. Journal of Business Ethics, DOI 10.1007/s10551-013-20191

Anand, V., Dacin, T., \& Murphy, T. (2014). The Continued Need for Diversity in Fraud Research. Journal of Business Research, DOI: 10.1007/s10551-014-2494-z

Ashforth, B., \& Anand, V. (2003). The normalization of corruption in organizations. Research in Organizational Behavior, 24, 1-52.

Bank of England. (2013). Bank of England response to the Final Report of the Parliamentary Commission on Banking Standards. Retrieved from:

http://www.bankofengland.co.uk/publications/Documents/news/2013/pcbsresponse.pd1> 15.03.2015.

Barak, G. (1998). Integrating Criminologies. Boston, MA: Allyn \& Bacon.

Beasley, M. S., Carcello, J. V., Hermanson, D. R., \& Neal, T. (2010). Fraudulent financial reporting 1998-2007: An analysis of U.S. public companies. Durham, NC: COSO.

Beasley, M., Carcello, J., Hermanson, D., \& Lapides, P. (2000). Fraudulent financial reporting: Consideration of industry traits and corporate governance mechanisms. Accounting Horizons, 14(4), 441-454.

Beattie , V., Fearnley, S \& Hines, T. (2011). Reaching key financial reporting decisions: How directors and auditors interact. London: Wiley.

Bell, T., \& Carcello, J. (2000). A decision aid for assessing the likelihood of fraudulent financial reporting. Auditing: A Journal of Practice and Theory, 19(1), 169-184.

Beneish. M.D., \& Vargus, M. (2002) Insider Trading, Earnings Quality, and Accrual Mispricing. The Accounting Review, 77(4), 755-791.

Beneish, D., Billings, M., \& Hodder, L. (2008). Internal Control Weaknesses and Information Uncertainty. The Accounting Review, 83(3), 665-703.

Bishop, C., DeZoort, F., \& Hermanson, D. (2017). The Effect of CEO Social Influence Pressure and CFO Accounting Experience on CFO Financial Reporting Decisions. AUDITING: A Journal of Practice \& Theory, 36(1), 21-41. 
Bouhana, N., \& Wikström, P-O. H. (2008). Theorising Terrorism as Moral Action: A Scoping Study. Report to the Counter-Terrorism Science and Technology Centre, Ministry of Defence, May. London: Jill Dando Institute of Crime Science. Retrieved from: http://www.pads.ac.uk/Documents/Terrorism_as_moral_action.pdf.

Bouhana, N., \& Wikström, P-O. H. (2011). Al Qa'ida-influenced radicalization: A rapid evidence assessment guided by situational action theory. Scientific Report, Home Office. Retrieved from https://www.gov.uk/government/uploads/system/uploads/.../occ97.pdf.

Braithwaite, J. (2000). The New Regulatory State and the Transformation of Criminology. British Journal of Criminology, 40(2), 222-38.

Braithwaite, J. (2013). Flipping markets to virtue with qui tam and restorative justice. Accounting Organization, and Society, 38(6-7), 458-468.

Brennan, N., \& Conroy, J. (2013). Executive hubris: the case of a bank CEO. Accounting, Auditing \& Accountability Journal, 26(2), 172 - 195.

Bruinsma, G., Pauwels, L., Weerman, F., \& Bernasco, W. (2015). Situational Action Theory: CrossSectional and Cross-Lagged Tests of Its Core Propositions . Canadian Journal of Criminology and Criminal Justice, DOI: http://dx.doi.org/10.3138/cjccj.2013.E24

Carcello , J., \& Nagy, A . (2004) . Audit firm tenure and fraudulent financial reporting . Auditing: A Journal of Practice and Theory, 23(2), 55- 69 .

CFTC. (2012). Examples of Misconduct From Written Communications.. US Commodity Futures Trading Commission. Retrieved from:

http://www.cftc.gov/idc/groups/public/@newsroom/documents/file/abobank.pdf

CFTC. (2012). Order: in the matter of Barclays Bank (June 27). US Commodity Futures Trading Commission. Retrieved from www.cftc.gov/ucm/groups/public/ @lrenforcementactions/documents/legalpleading/enfbarclaysorder062712.pdf.

CFTC. (2012). Order: in the matter of UBS AG (December 19). US Commodity Futures Trading Commission. Retrieved from www.cftc.gov/ucm/groups/public/ @lrenforcementactions/documents/legalpleading/enfubsorder121912.pdf.

CFT\&. (2013). Order: in the matter of RBS (February 6). US Commodity Futures Trading Commission. Retrieved from www. http://www.cftc.gov/idc/groups/public/@lrenforcementactions/documents/legalpleading/enfrbsor der020613.pdf

Choo, F., \& Tan, K. (2007). An “American Dream” theory of corporate executive fraud. Accounting Forum, 31(2), 203-215. 
Chung, J., Farrar, J., Puri, P.,_\&Thorne, L. (2010). Auditor liability to third parties after SarbanesOxley: An international comparison of regulatory and legal reforms. Journal of International Accounting, Auditing and Taxation, 19, 66-78.

Clikeman, P. M. (2009). Called to account: Fourteen financial frauds that shaped the American accounting profession. New York: Routledge.

Clor-Proell, S.M., Proell, C. \&Kaplan, S. (2015). The Impact of Budget Goal Difficulty and Promotion Availability on Employee Fraud. Journal of Business Ethic, DOI 10.1007/s10551-013-2021-7

Cohen, J., Ding, Y., Lesage, C., \& Stolowy, H. (2010). Corporate fraud and managers’ behavior: Evidence from the press. Journal of Business Ethics, 95, 271-315.

Coleman, J.W. (1987). Toward an Integrated Theory of White-Collar Crime, American Journal of Sociology, 93(2), pp. 406-439.

Colombo, J. (2014). This New Libor 'Scandal' Will Cause a Terrifying Financial Crisis. Forbes. Retrieved from http://www.forbes.com/sites/jessecolombo/2014/06/03/this-new-libor-scandalwill-cause-a-terrifying-financial-crisis/.

Cooper, D., Dacin., T., \& Palmer, D. (2013). Fraud in accounting, organizations and society: Extending the boundaries of research. Accounting, Organization, and Society, 38, (6-7), 440-457.

Cortese, C.l., Irvine, H.J., \& Kaidonis, M.A. (2010). Powerful players: How constituents captured the setting of IFRS 6, an accounting standard for the extractive industries.” Accounting Forum, 34(2), 76-88.

Davis, J. L., \& Pesch, H. L. (2013). Fraud dynamics and controls in organizations. Accounting, Organization and Society, 38(6-7), 469-483.

Dedoulis, E. (2006). The Code of Ethics and the development of the auditing profession in Greece, the period 1992-2002. Accounting Forum, 30(2), 155-178.

DeFond , M., \& Francis, J. (2005) . Audit research after Sarbanes-Oxley . Auditing: A Journal of Practice and Theory, 24(S-1), 5-30.

Dechow, P., Sloan, S., \& Sweeney, A. (1996). Causes and Consequences of Earnings Manipulations: An Analysis of Firms Subject to Enforcement Actions by the SEC. Contemporary Accounting Research, 13(1), 1-36.

Dellaportas, S. (2013). Conversations with inmate accountants: Motivation, opportunity and the fraud triangle. Accounting Forum, 37(1), 29-39.

Donegan, J. J., \& Ganon, M. W. (2008). Strain, differential association, and coercion: Insights from the criminology literature on causes of accountant's misconduct. Advances in Public Interest Accounting, 8,1-20. 
Dorminey, J. W., Fleming, A. S., Kranacher, M.J., \& Riley, R. A. Jr. (2010). Beyond the fraud triangle. CPA Journal, 80(7), 16-23.

Dorminey, J., S. Fleming, M. Kranacher, \& R. Riley. (2012). The evolution of fraud theory. Issues in Accounting Education, 27(2), 555-79.

Erickson, M., Hanlon, M., \& Maydew, E. L. (2004). How much will firms pay for earnings that do not exist? Evidence of taxes paid on allegedly fraudulent earnings. The Accounting Review, 79(2), 387-408.

Erickson, M., Hanlon, M., \& Maydew, E. (2006). Is there a link between executive equity incentives and accounting fraud? Journal of Accounting Research, 44(1), 113-143.

Evans, D.M. (1859 reprinted 2013). Facts Failures and Frauds, Revelations Financial Mercantile Criminal. London: Groombridge and Sons.

Farber, D. B. (2005). Restoring trust after fraud: Does corporate governance matter? The Accounting Review, 80(2), 539-561.

Felsted, A., \& Oakley, D. (2014). Tesco admits overstating profits for longer. The Financial Times. Retrieved from: https://www.ft.com/content/ce49c8a4-5a7b-11e4-b449-00144feab7de

Financial Service Authority. (2012a). Final Notice: Barclays Bank Plc. Retrieved from http://www.fca.org.uk/your-fca/documents/final-notices/2013/fsa-final-notice-2012-barclaysbank-plc.

Financial Service Authority. (2012b). Final Notice: Cattles Limited. Retrieved from http://www.fsa.gov.uk/static/pubs/final/cattles-ltd.pdf.

Financial Service Authority. (2012c). Final Notice: UBS AG. Retrieved from https://www.fca.org.uk/publication/final-notices/ubs.pdf

Financial Service Authority. (2012d). Final Notice: James Corr: Retrieved from: https://www.frc.org.uk/Our-Work/Publications/Professional-Discipline/Tribunal-Report-JamesCorr/Associated-documents/Final-Notice-James-Corr.aspx

Financial Service Authority. (2012e). Final Notice: Peter Miller: Retrieved from: http://www.fsa.gov.uk/static/pubs/final/peter-douglas-miller.pdf

Financial Service Authority. (2013). Final Notice: The Royal Bank of Scotland plc. Retrieved from http://www.fsa.gov.uk/static/pubs/final/rbs.pdf

Fisheł, J., Blottiax, M., Daniel, S., Oliveria, H., Green, D., Osaka, O., \& Trakkidi, A. (2013). The global financial crisis: the case for a stronger criminal response. Law and Financial Markets Review, 7(3),159-166. 
Flyvbjerg, B. (2006). Five misunderstandings about case-study research. Qualitative Inquiry, 12(2), 219-245.

Free, C., Macintosh, N., \& Stein, M. (2007). Management controls: The organizational fraud triangle of leadership, culture and control in Enron. Ivey Business Journal, 71(6), 1-5.

Free, C., \& Murphy, P. (2013). The ties that bind: The decision to co-offend in fraud. Contemporary Accounting Research, 32(1), 18-54.

Gabbioneta, C., Greenwood, R., Mazzola, P., \& Minoja, M. (2013). The influence of the institutional context on corporate illegality. Accounting, Organizations and Society. http://dx.doi.org/10.1016/j.aos.2012.09.002.

Galbraith, J.K. (2004). The economics of innocent fraud: Truth for our time. New York: Houghton Mifflin Harcourt.

Gietzmann, M. B., \& Pettinicchio, A. K. (2014). External auditor reassessment of client business risk following the issuance of a Comment Letter by the SEC. European Accounting Review, 23(1), 57-85.

Gottfredson, M., \& Hirschi, T. (1990). A General theory of crime. Stanford, CA: Stanford University Press.

Guilcher, G. (2005). The Press Mania during the Railway Mania, 1844-45. Journal of Railway and Canal Historical Society, 191, 26-33.

Gullkvist, B., \& Jokipii, A. (2013). Perceived importance of red flags across fraud types. Critical Perspectives on Accounting, 24(1), 44-61.

Green, S. (2004). Moral ambiguity in white-collar criminal law. Notre Dame Journal of Law Ethics and Public Policy, 18, 502-513.

Greve, H., Palmer, D., \& Pozner, J. (2010). Organizations gone wild: The causes, processes and consequences of organizational misconduct. The Academy of Management Annals, 4(1), 53-107.

Hoffman, V. B., \& Zimbelman, M. F. (2009). Do strategic reason and brainstorming help auditors change their standard audit procedures in response to fraud risk. The Accounting Review, 84(3), 811-837.

Hogan, C. E., Rezaee, Z., Riley, R. A., Jr., \& Velury, U. K. (2008). Financial statement fraud: Insights from the academic literature. Auditing: A Journal of Practice \& Theory, 27(2), 231-252.

Hirtenlehner, H., \& Hardie, B. (2016). On the Conditional Relevance of Controls: An Application of Situational Action Theory to Shoplifting. Deviant Behaviour, 37(3), 315-331. 
Hirtenlehner, H., Pauwels, H., \& Mesko, G. ( 2014). Is the Effect of Perceived Deterrence on Juvenile Offending Contingent on the Level of Self-Control? Results from Three Countries.” British Journal of Criminology, 54, 109-127.

HM Treasury. (2013). The Government's response to the Parliamentary Commission on Banking Standards. Retrieved from https://www.gov.uk/government/uploads/system/uploads/attachment_data/file/211047/gov_respo nse_to_the_parliamentary_commission_on_banking_standards.pdf.

Hollow, M. (2015). Rouge trading: A history of financial fraud in interwar Britain. London: Palgrave.

Holt, N. (2012). Former Welcome MD gets FSA ban and fine. Retrieved from http://www.mortgagestrategy.co.uk/news-and-features/latest-news/former-welcome-md-gets-fsaban-and-fine/1059454.article.

Humphrey, C., Loft, A., \& Woods, A. (2009). The global audit profession and the international financial architecture: Understanding regulatory relationships at a time of financial crisis. Accounting, Organizations and Society, 34(6-7), 810-825.

Lehman, C.,_\& Okcabol, F.(2005).Accounting for crime. Critical Perspectives on Accounting, 16(5), 613-639.

Jeffrey, C.R. (1990). Criminology: An interdisciplinary approach. Englewood Cliffs, NJ: Prentice Hall.

Jones, M. J. (ed.). (2011). Creative accounting, fraud and international accounting scandals. Chichester: Wiley

Kardell, R. (2015). Defrauding for fun not need Fraud Triangle doesn't explain fraudsters who steal only for enjoyment. Fraud Magazine. Retrieved from http://www.fraudmagazine.com/article.aspx?id=4294989031.

Knechel, W., \&Vanstraelen, A. (2007). The relationship between auditor tenure and audit quality implied by going concern opinions. Auditing: A Journal of Practice and Theory, 26(1), 113-131.

Lakoff, G. (1987). Women, fire and dangerous things-What categories reveal about the mind. London: University of Chicago Press.

Lokanan, M.E. (2014). How senior managers perpetuate accounting fraud? Lessons for fraud examiners from an instructional case. Journal of Financial Crime, 21(4), 411-423.

Lokanan, M.E. (2015a). Challenges to the fraud triangle: Questions on its usefulness. Accounting Forum, doi:10.1016/j.accfor.2015.05.002

Lokanan, M.E. (2015b). Securities regulation: Opportunities exist for IIROC to regulate responsively. Administration \& Society. doi: 10.1177/0095399715584637 
Lord, A., \& DeZoort, F. (2001). The impact of commitment and moral reasoning on auditors' responses to social influence pressure. Accounting, Organizations and Society, 26(3), 215-235.

Lynch, M., McGurrin, D., \& Fenwick, M. (2004). Disappearing act: The representation of corporate crime research in criminological literature. Journal of Criminal Justice, 32, 389-398.

Mayhew, B. W., \& Murphy, P. (2014). The Impact of Authority on Reporting Behavior, Rationalization and Affect. Contemporary Accounting Research, 31(2), 420-443.

Matthews, D. (2005). London and County Securities: a case study in audit and regulatory failure. Accounting, Auditing \& Accountability Journal, 18(4), 518-536.

Macintosh, N. B. (2009). Accounting and the truth of earnings reports: Philosophical considerations. European Accounting Review, 18(1), 141-175.

Mitchell, A., Sikka, P., \& Willmott, H. (1998). Sweeping it under the carpet: The role of accountancy firms in money laundering. Accounting, Organizations and Society, 23(5-6), 589-607.

Mollenkamp, C., \& Whitehouse, M. (2008). Study Casts Doubt on Key Rate: WSJ Analysis Suggests Banks May Have Reported Flawed Interest Data for Libor. Retrieved from: https://www.wsj.com/articles/SB121200703762027135

Monticini, A., \& Thornton, D. (2013). The effect of underreporting on LIBOR Rates. Retrieved from: http://research.stlouisfed.org/wp/2013/2013-008.pdf.

Morales, J., Gendron, Y., \& Guénin-Paracini, H. (2014). The construction of the risky individual and vigilant organization: A genealogy of the fraud triangle. Accounting, Organizations and Society, 39(3), 170-194.

Morgan, E., \& Thomas, W. (1962). The stock exchange: Its history and functions. London: Eleck Books.

Murphy P. (2012). Attitude, machiavellianism and the rationalization of misreporting. Accounting, Organizations and Society, 37(5), 242-259.

Murphy, P., \& Dacin, T. (2011). Psychological pathways to fraud: Understanding and preventing fraud in organizations. Journal of Business Ethics, 101(4), 601-618.

Murphy, P., \& Free, C. (2016). Broadening the Fraud Triangle: Instrumental Climate and Fraud. Behavioral Research in Accounting, 28(1), 41-56.

Nelken, D. (1994). White-collar crime. Aldershot: Dartmouth.

Neu, D., Everett, J., \& Rahaman, A. (2013a). Internal Auditing and Corruption within Government: The Case of the Canadian Sponsorship Program. Contemporary Accounting Research, 30(3), 12231250. 
Neu, D., Everett, J., Rahaman, A., \& Martinez, D. (2013b). Accounting and networks of Corruption. Accounting, Organization and Society, 38(6-7), 505-524.

O’Connell B. (2004). Enron. Con: "He that filches from me my good name ... makes me poor indeed”. Critical Perspectives on Accounting, 15(6-7), 733-749.

O'Toole, J. (2012). Explaining the Libor interest rate mess. CNN. Retrieved from http://money.cnn.com/2012/07/03/investing/libor-interest-rate-faq/index.htm.

Rae, K.,_\& Subramaniam, N. (2008). Quality of internal control procedures: Antecedents and moderating effect on organizational justice and employee fraud. Managerial Auditing Journal, 23(2), 104-124.

Ramamoorti, S. (2008). The psychology and sociology of fraud: Integrating the behavioral sciences component into fraud and forensic accounting curricula. Issues in Accounting Education, 23(4), 521-533.

Rappaport, L. (2012). Bank settles Iran money case: Standard Chartered to pay New York Regulator \$340 Million; Other Probes Loom. The Wall Street Journal. Retrieved from http://www.wsj.com/articles/SB10000872396390444318104577589380427559426.

Russell, J. (2012). UBS rogue trader Kweku Adoboli jailed for seven years. The Telegraph. Retrieved from http://www.telegraph.co.uk/finance/financial-crime/9690206/UBS-rogue-trader-KwekuAdoboli-jailed-for-seven-years.html.

Payne, B. (2010). White-Collar Crime: A Text/Reader: A Text/Reader. Thousands Oaks, CA: Sage.

Parliamentary Commission on Banking Standards. (2013a). Changing Banking for Good, First Report, House of Lords 27-1/House of Commons 175-1, Vol. 1.Retrieved from: http://www.parliament.uk/documents/banking-commission/Banking-final-report-volume-i.pdf

Parliamentary Commission on Banking Standards. (2013b). Changing Banking for Good, First Report, House of Lords 27-11/House of Commons 175-11, Vol. II. Retrieved from: http:/www.parliament.uk/documents/banking-commission/Banking-final-report-vol-ii.pdf

Parliamentary Commission on Banking Standards. (2013c). Changing Banking for Good: Oral evidence taken by the Commission, House of Lords 27-111/House of Commons 175-11, Vol. III. Retrieved from: https:/www.publications.parliament.uk/pa/jt201314/jtselect/jtpcbs/27/27iii.pdf

Parliamentary Commission on Banking Standards. (2013d). Changing Banking for Good: Written evidence to the Commission, House of Lords 27-IV/House of Commons 175-1V, Vol. IV. Retrieved from: https://www.publications.parliament.uk/pa/jt201314/jtselect/jtpcbs/27/27iv.pdf

Parliamentary Commission on Banking Standards. (2013e). Changing Banking for Good: Written evidence to the Commission, House of Lords 27-V/House of Commons 175-V, Vol. V. Retrieved from: https://www.publications.parliament.uk/pa/jt201314/jtselect/jtpcbs/27/27v.pdf 
Parliamentary Commission on Banking Standards. (2013f). Changing Banking for Good: Written evidence taken by Sub-Committees A and B, House of Lords 27-VII/House of Commons 175VII, Vol. VII. Retrieved from: https://www.publications.parliament.uk/pa/jt201314/jtselect/jtpcbs/27/27vii.pdf

Parliamentary Commission on Banking Standards. (2013g). Changing Banking for Good: Oral and writhttps://www.publications.parliament.uk/pa/jt201314/jtselect/jtpcbs/27/27vi.pdf

Parliamentary Commission on Banking Standards. (2013h). Changing Banking for Good: Oral and written evidence taken by Sub-Committees C, D, E, F and G, House of Lords 27-VIII/House of Commons 175-VIII, Vol. VIII. Retrieved from: https://www.publications.parliament.uk/pa/jt201314/jtselect/jtpcbs/27/27viii.pdf

Parliamentary Commission on Banking Standards. (2013i). Changing Banking for Good: Oral and written evidence taken by Sub-Committees H, I, J and K, House of Lords 27-IX/House of Commons 175-IX, Vol. IX. Retrieved from: https://www.publications.parliament.uk/pa/jt201314/jtselect/jtpcbs/27/27ix.pdf

Pauwels, L., \& Svensson, R. (2010). Informal controls and the explanation of propensity to offend: A test in two urban samples. European Journal on Criminal Policy and Research, 16(1), 15-27.

Platt, E., \& Lopez, L. (2012). Crazy details about the bank that's been accused of transferring $\$ 250$ billion to Iran. Business Insider. Retrieved from http://www.businessinsider.com/standardchartered-iran-details-2012-8?IR=T.

Power, M. (2013). The apparatus of fraud risk. Accounting, Organizations and Society, 38(6-7), 535543.

Price, M., \& Norris, D. (2009). White-Collar Crime: Corporate and Securities and Commodities Fraud. The Journal of the American Academy of Psychiatry and the Law, 37 (4), 538-544.

PwC. (2016). Economic crime is up and detection is down: Time to take a proactive approach. Global economic crime survey 2016. Retrieved from: https://www.pwc.com/ca/en/deals/publications/2016-02-Global-Crime-Survey-Canada.pdf

Rezaee, Z. (2002). Financial Statement Fraud: Prevention and Detection. New York, NY: John Wiley and Sons.

Rezałe, Z._(2005).Causes, consequences and deterrence of financial statement fraud. Critical Perspectives on Accounting, 16, 277-298.

Ridley, K., Franklin, J., \& Viswanatha, A. (2014). Regulators fine global banks $\$ 4.3$ billion in currency investigation. Reuters. Retrieved from http://www.reuters.com/article/2014/11/12/us-banksforex-settlement-cftc-idUSKCNOIW0E520141112. 
Ruddick, G. (2014). Tesco warns profits overstated by £250m as it uncovers 'serious issue'. The Telegraph. Retrieved from:

http://www.telegraph.co.uk/finance/newsbysector/epic/tsco/11112704/Tesco-warns-profitsoverstated-by-250m-as-it-uncovers-serious-issue.html

Samsonova-Taddei, A., \& Humphrey, C. (2015). Risk and the construction of a European audit policy agenda: The case of auditor liability. Accounting, Organizations and Society, 45(1), 55-72.

Sartre, J. (1943). Being and Nothingness. New York: Washington Square Press.

Schuchter, A., \& Levi, M. (2015). Beyond the fraud triangle: Swiss and Austrian elite fraudsters. Accounting Forum, 39(3), 176-187

Sikka, P. (2008). Globalization and its discontents: Accounting firms buy limited liability partnership legislation in Jersey. Accounting, Auditing and Accountability Journal, 21(3), 398-426.

Sikka, P. (2010). Smoke and mirrors: Corporate social responsibility and tax avoidance, Accounting Forum, 34 (3/4), 153-168.

Sikka, P. (2015). The corrosive effects of neoliberalism on the UK financial crises and auditing practices: A dead-end for reforms. Accounting Forum, 39(1), 1-18.

Stalebrink, O., \& Sacco, J. (2007). Rationalization of financial statement fraud in government: An Austrian perspective. Critical Perspectives on Accounting, 18(4), 489-507.

Stuebs, M., \& Wilkinson, B. (2010). Ethics and the tax profession: Restoring the public interest focus. Accounting \& the Public Interest, 10, 13-35.

Strand Norman, C., Rose, A.M., \& Rose, J.M. (2010).Internal audit reporting lines, fraud risk decomposition, and assessments of audit risk. Accounting, Organizations and Society, 35(5), 546-557.

Sutherland, E.H. (1937). The professional thief. Chicago: The University of Chicago.

Taylor, J. (2007). Company fraud in Victorian Britain: The Royal British Bank Scandal of 1856, European Historical Review, 122 (497), 700-724.

Vaughan, L., Finch, G., \& Tan. A. (2012). RBS managers said to condone manipulation of Libor rates. Bloomberg. Retrieved from http://www.bloomberg.com/news/articles/2012-09-24/rbsmanagers-said-to-condone-manipulation-of-libor-rates.

Wikström, P-O H. (2004). Crime as alternative: Towards a cross-level situational action theory of crime causation. In J. McCord (Ed.), Beyond empiricism: Institutions and intentions in the study of crime: Advances in criminological theory (pp. 1-37). New Brunswick: Transaction. 
Wikström, P-O H, (2010a). Explaining crime as moral actions. In S. Hiltin \& S. Vaisey (eds.). Handbook of the sociology of morality (pp.201-239). New York: Springer.

Wikström, P-O H. (2010b). Situational action theory. In F. Cullen \& P. Wilcox (Eds.) Encyclopedia of Criminological Theory (pp. 1001-1009). London: SAGE publications.

Wikström, P-O H. (2010c). Explaining Crime as Moral Actions. In S Hitlin and S Vaisey (Eds.). Handbook of the Sociology of Morality (pp. 211-241). New York, NY: Springer

Wikström, P-O.H. (2011). Does everything matter? Addressing problems of causation and explanation in the study of crime. In: J.M. McGloin, C.J. Silverman, \& L.W. Kennedy (Eds.). When Crime Appears: The Role of Emergence (pp. 53-73). New York, NY: Routledge.

Wikström, P-O H. (2013). The Peterborough Adolescent and Young Adult Development Study (PADS+). Retrieved from http://www.pads.ac.uk/pages/research/pads.html.

Wikström,-, P-O H. (2015). Crime propensity, criminogenic exposure and crime involvement in early to mid adolescence. Monatsschrift fur Kriminologie und Strafrechtsreform, 92 (2), 253-266.

Wikström, P-O H., \& Treiber, K.H. (2009). Violence as situational action. International Journal of Conflict and Violence, 3(1), 75-96.

Wikström, P-O H., Oberwittler, D, Treiber, K., \& Hadie, B. (2012). 'Breaking Rules': The Social and Situational Dynamics of Young People’s Urban Crime. Oxford: Oxford University Press.

Williams, J. W. (2008). The lessons of ‘Enron’: Media accounts, corporate crimes, and financial markets. Theoretical Criminology, 12(4), 471-499.

Williams, J.W. (2013). Regulatory technologies, risky subjects, and financial boundaries: Governing 'fraud' in the financial markets. Accounting, Organization and Society, 38(6-7), 544-558.

Wilson, S. (2014). The origins of modern financial crime: Historical foundations and current problems in Britain. New York: Routledge.

Wolfe, D., \& Hermonson, D. (2004). The fraud diamond: Considering the four elements of fraud. The CPA Journal. Retrieved from http://www.nysscpa.org/cpajournal/2004/1204/essentials/p38.htm. 